\title{
The Plant Host Brassica napus Induces in the Pathogen Verticillium Iongisporum the Expression of Functional Catalase Peroxidase Which Is Required for the Late Phase of Disease
}

\author{
Seema Singh, ${ }^{1}$ Susanna A. Braus-Stromeyer, ${ }^{1}$ Christian Timpner, ${ }^{1}$ Oliver Valerius, ${ }^{1}$ \\ Andreas von Tiedemann, ${ }^{2}$ Petr Karlovsky, ${ }^{2}$ Christine Druebert, ${ }^{3}$ Andrea Polle, ${ }^{3}$ and Gerhard H. Braus ${ }^{1}$ \\ ${ }^{1}$ Institut für Mikrobiologie und Genetik, ${ }^{2}$ Department für Nutzpflanzenwissenschaften, and ${ }^{3}$ Abteilung Forstbotanik und \\ Baumphysiologie, Georg-August Universität, 37077 Göttingen, Germany
}

Submitted 29 August 2011. Accepted 14 November 2011.

\begin{abstract}
The devastating soilborne fungal pathogen Verticillium longisporum is host specific to members of the family Brassicaceae, including oilseed rape (Brassica napus) as the economically most important crop. The fungus infects through the roots and causes stunting and early senescence of susceptible host plants and a marked decrease in crop yield. We show here that $V$. longisporum reacts to the presence of $B$. napus xylem sap with the production of six distinct upregulated and eight downregulated proteins visualized by two-dimensional gel electrophoresis. Identification of 10 proteins by mass spectrometry revealed that all upregulated proteins are involved in oxidative stress response. The $V$. longisporum catalase peroxidase (VICPEA) was the most upregulated protein and is encoded by two isogenes, VlcpeA-1 and VlcpeA-2. Both genes are $98 \%$ identical, corroborating the diploid or "amphihaploid" status of the fungus. Knock downs of both VlcpeA genes reduced protein expression by $80 \%$ and resulted in sensitivity against reactive oxygen species. Whereas saprophytic growth and the initial phase of the plant infection were phenotypically unaffected, the mutants were not able to perform the late phases of disease. We propose that the catalase peroxidase plays a role in protecting the fungus from the oxidative stress generated by the host plant at an advanced phase of the disease.
\end{abstract}

The genus Verticillium includes several pathogenic fungi affecting trees, herbaceous plants, and plantation crops. Verticillium longisporum, $V$. dahlia, and $V$. albo-atrum have become a serious threat to commercially important crops in many agricultural areas (Kroeker 1976; Zielinski and Sadowski 1995). V. longisporum is a vascular pathogen of Brassica napus. Since the $1960 \mathrm{~s}$, Verticillium wilt has become a major threat to oilseed crops in northern Europe, including Sweden, Germany,

Nucleotide sequence data is available in the EMBL database under accession numbers FR717672 and FR717673 for cpeA1 and cpeA2, respectively.

Current address for S. Singh: Maine Medical Center Research Institute, Scarborough, ME 04074, U.S.A.

Corresponding author: G. H. Braus; Telephone: +49 5513937 71; Fax: +49 5513938 20; E-mail: gbraus@gwdg.de

* The $e$-Xtra logo stands for "electronic extra" and indicates that two supplementary figures and one supplementary table are published online and that Figure 7 appears in color online. and Poland, and also France (Karapapa et al. 1997; Zeise and von Tiedemann 2002a and b). In Germany, V. longisporum infection on rapeseed has significantly increased since the 1980s (Daebeler et al. 1988; Günzelmann and Paul 1990; Zeise and Seidel 1990). The need for rapeseed oil is increasing due to the fact that it is a healthy vegetable oil and also a renewable resource for the oleochemical industry (Zielinski and Sadowski 1995). With expanding agricultural area for cultivation of rapeseed and the relatively intense crop rotation, this disease has become a menace to oilseed rape production, particularly in Europe (Zielinski and Sadowski 1995). V. longisporum does not generate true wilting symptoms but, instead, premature senescence and ripening, which can result in massive yield reductions of up to 50 to $70 \%$ (Dunker et al. 2006; Kroeker 1976; Zielinski and Sadowski 1995).

V. longisporum causes only one cycle of disease and inoculum production during a growing season (monocyclic disease). $V$. longisporum is an opportunistic phytopathogen with a life cycle which can be divided into three phases: dormant, parasitic, and saprophytic. In the dormant phase, microsclerotia serve as resting dormant spores of $V$. longisporum and are present in the soil. Their germination is inhibited by microbiostasis or mycostasis. Root exudates containing excess carbon and nitrogen released in the rhizosphere of plants are probably stimulating microsclerotia to germinate (Huisman 1982; Mol et al. 1995). Hyphae that grow out of the germinating microsclerotia can traverse a limited distance, possibly directed by nutrient gradients, to reach potential host plants and then enter the parasitic stage by infecting the host plant.

$V$. longisporum is remarkable because the fungus is limited to the xylem vessels during the biotrophic phase of its life cycle. In order to propagate in the plant, it must derive nutrients from the xylem sap; however, studies on the nutritional condition for the pathogen in the xylem are limited. The xylem transports mineral-containing water from the soil to the aerial plant parts. In addition, the xylem sap contains amino acids, organic acids, and sugars (Lopez-Millan et al. 2000). It has been reported recently that chorismate synthase silencing in $V$. longisporum reduced the efficiency of plant infection and induced cross-pathway control in the plant xylem (Singh et al. 2010). V. longisporum has to react quickly and respond to the host environment by expression of genes that facilitate adaptation to conditions encountered during colonization of the xylem. Such genes might play a role in aiding the fungus to avoid recognition, counteract plant defense responses, use 
scarce or unique nutrients in the xylem, and influence the plant host, rapeseed, to alter its internal environment to better suit the needs of the invading fungus. In a proteomic analysis of the xylem sap of B. napus, 69 proteins belonging to the functional classes of peroxidases, proteases, defense-related proteins, lectins, and cell wall metabolism and remodeling proteins were identified (Kehr et al. 2005). Only some of these proteins were upregulated in response to V. longisporum (Floerl et al. 2008). Changes in the composition of the xylem sap due to the infection with V. longisporum could be detected (Floerl et al. 2008; Ratzinger et al. 2009).

Proteomics, based on a combination of two-dimensional (2-DE) followed by mass spectrometry (MS) analysis, is a key research tool used to study microbial pathogens in terms of their proteome maps, stage-specific proteomics, and pathogenicity factors (Bhadauria et al. 2007; Jordan et al. 2006). In $V$. dahliae, a fungus very closely related to $V$. longisporum, a comparative analysis of mycelial proteomes has recently been published (El-Bebany et al. 2010). The two species differ in their host preferences, morphology, and geographical distribution. Functional genomics of $V$. dahliae have been investigated in a few studies (Klimes and Dobinson 2006; Klosterman et al. 2011) but a comprehensive proteomics analysis of V. longisporum has not been reported. Plants protect themselves from an invading pathogen by various responses which strengthen barriers against the invader or weaken the pathogen (Apostol et al. 1989; Hammond-Kosack and Jones 1996; van Loon et al. 2006). One of the earliest responses to an infection by a pathogen leads to the rapid production of reactive oxygen species (ROS) (e.g., hydrogen peroxide $\left[\mathrm{H}_{2} \mathrm{O}_{2}\right]$, superoxide radicals, or hydroxyl ions termed oxidative burst) (Lamb and Dixon 1997; Mayer et al. 2001). The major ROS leading to oxidative burst is $\mathrm{H}_{2} \mathrm{O}_{2}$ (Wojtaszek 1997). ROS are able to oxidize proteins, lipids, and nucleic acids, which leads to damage in cellular structures (Medentsev et al. 2001). As a response to oxidative burst, plant pathogens can activate various enzymes such as catalases or peroxidases that are capable of removing $\mathrm{H}_{2} \mathrm{O}_{2}$ or other ROS (Mayer et al. 2001). Claviceps purpurea secretes catalases as response to host plant defense mechanisms (Garre et al. 1998). Catalases have been identified as virulence factors in the pathogens Candida albicans or Agrobacterium tumefa- ciens (Wysong et al. 1998; Xu and Pan 2000). The catalase CatB of Magnaporthe grisea strengthens the fungal cell wall (Skamnioti et al. 2007), whereas Des1 of M. oryzae compromises ROS-mediated plant defense (Chi et al. 2009) and MoHyr1 is part of the ROS detoxification mechanism (Huang et al. 2011). The transmembrane protein TmpL is required for intracellular redox homeostasis and virulence in a plant and an animal fungal pathogen (Kim et al. 2009).

Here, we use a proteomic approach to screen for proteins which are expressed when $V$. longisporum senses the xylem sap of the plant. We identified the most prominent statistically relevant reaction as the increase of a bifunctional catalase peroxidase. The two corresponding isogenes of the catalase peroxidase were identified and silenced in $V$. longisporum using RNAi-mediated gene silencing. Plant infection assays in $B$. napus revealed that the catalase peroxidase is required for late phases of the disease.

\section{RESULTS}

Xylem sap of $B$. napus inhibits growth of $\boldsymbol{V}$. longisporum and affects fungal development.

We analyzed how the addition of xylem sap of the host plant affects growth or life cycle progression of the pathogen $V$. longisporum. In a first approach, we tested whether xylem sap enhances or inhibits fungal growth. Fungal growth is drastically inhibited during cultivation in xylem sap of infected or uninfected plants (Fig. 1A). Macromolecules larger than $3 \mathrm{kDa}$ were separated from the xylem sap from infected as well as uninfected plants. Both samples were able to inhibit fungal growth when added to a standard complete medium for fungi (Fig. 1B), suggesting that the plant synthesizes proteins which inhibit the fungus.

We then analyzed whether the xylem sap without this protein fraction affects the fungus. Two different solid agar growth media-Czapek Dox agar (CDA) (Nell et al. 2006) or simulated xylem fluid medium (SXM) - were tested. Differences in the fungal phenotype when filtered xylem sap in a volume of one-seventh of the media volume was added were already apparent for both media 3 days after inoculation. Filtered xylem sap stimulates fungal growth, melanization, or the formation of
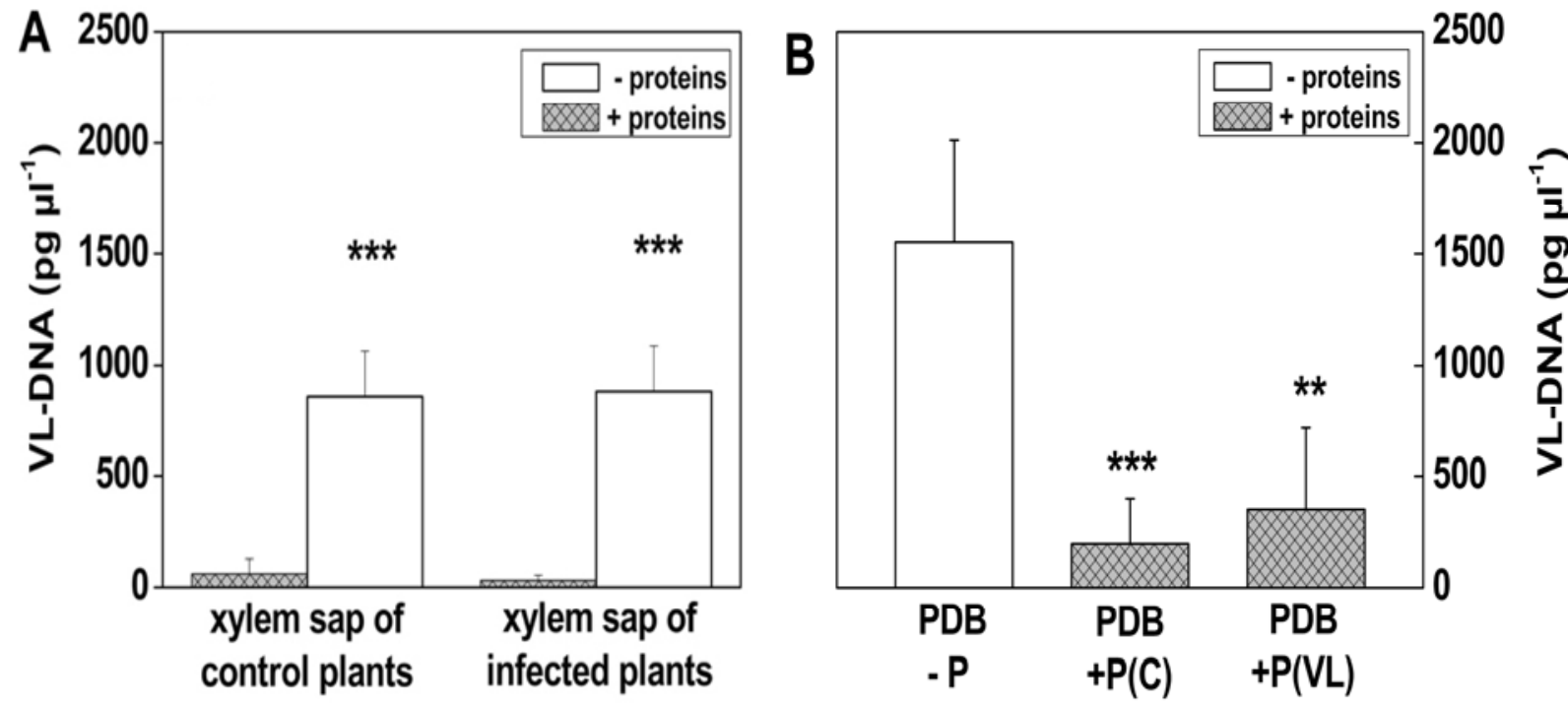

Fig. 1. Inhibition of Verticillium longisporum growth by xylem sap proteins of oilseed rape (Brassica napus). A, V. longisporum DNA after 3 days of growth in filtered (white bars) or unfiltered (hatched bars) xylem sap of infected or control plants. B, V. longisporum DNA after 3 days of growth in potato dextrose broth (PDB) medium with filtered (white bars; without xylem sap proteins: $-\mathrm{P}$ ) or unfiltered (hatched bars, with xylem sap proteins: $+\mathrm{P}$ ) of infected (VL) or control (C) plants. Data indicate means $(n=5) \pm$ standard deviation. Significant differences between samples with and without proteins are illustrated by asterisks (*** and $* *$ indicate $P \leq 0.001$ and 0.01 , respectively). Xylem sap was collected between 25 and 28 days postinfection. 
bud spores. The stimulating effect of the filtered xylem sap was quantified after 8 days of cultivation by counting spores. This revealed that filtered xylem sap can increase conidia formation more than twice, independently of the medium (Fig. 2). Further dilution of the xylem sap by a factor of 10 resulted in the same stimulation in fungal growth and melanization and increase in spore formation (data not shown).

\section{V. longisporum showed upregulated as well as downregulated proteins when grown in the presence of xylem sap of $B$. napus.}

The stimulating impact of xylem sap of B. napus on growth of $V$. longisporum was analyzed in more detail. Xylem sap was extracted from 42-day-old B. napus because it corresponded to the plant at 35 days postinoculation, when the disease symptoms are most severe. We examined changes in the intracellular proteome, which may occur after treating $V$. longisporum with the filtered xylem sap of $B$. napus ( 42 days old) which stimulates fungal growth. To identify the proteins that might be differentially expressed in $V$. longisporum by growth in the presence of xylem sap, we extracted intracellular proteins from 5-day-old liquid fungal cultures incubated with or without xylem sap for $8 \mathrm{~h}$. Comparison of six sets of Ruthenium II Tris-bathophenantroline disulfonate (RuBP) (Lamanda et al. 2004) stained 2-DE gels of these extracts clearly demonstrated that 2-DE analysis of protein samples exhibited reproducible gel images. More than 800 protein spots with a molecular weight between 10 and $120 \mathrm{kDa}$ and a pI ranging from $\mathrm{pH} 4.0$ to 7.0 were resolved for both conditions. A quantitative analysis using PDQuest software revealed six proteins (U1 to U6) upregulated and eight proteins (D1 to D8) downregulated compared with the controls. These are indicated by arrows in Figure 3A. Close-up views of the gels confirmed that the enhanced spots were differentially expressed compared with the control levels (Fig. 3B and C). The proteomic analysis was also performed using xylem sap from 35-day-old B. napus plants. Protein spots U1, U4, D2, and D3 showed no significant regulation compared with controls in this analysis. To test whether the xylem sap extracted from B. napus that was already infected with $V$. longisporum may influence the $V$. longisporum proteome more, the two-dimensional polyacrylamide gel electrophoresis (2D-PAGE) analysis was also performed using the xylem sap extracted from 42-day-old infected B. napus plants (35 days postinfection [dpi]) or 35-day-old infected B. napus plants (28 dpi). However, there was no significant difference found in protein expression between fungal cultures treated with xylem sap from $B$. napus uninfected versus infected with $V$. longisporum.
To identify the proteins, tryptic digestion of excised, selected differentially expressed protein spots was followed by a tandem MS (MS/MS) run; then, identification was achieved through homology searching with tentative sequences obtained by MS. The resulting identified proteins are shown in Table 1. Of the 14 selected protein spots, 10 protein spots could be successfully identified. Half of the identified proteins were found to be homologous to $V$. dahliae proteins and others to other fungal organisms such as Aspergillus nidulans and Neurospora crassa. The identification of most of the protein spots was also confirmed through the analysis of the MS/MS data sets with the PEAKS MS program (data not shown). Two upregulated (U5 and U6) and two downregulated (D2 and D7) proteins that were not identified by analysis with TURBOSequest also could not be identified by analysis with PEAKS that used the National Center for Biotechnology Information (NCBI) $\mathrm{nr}$ database; therefore, they may be $V$. longisporum proteins that are not so well conserved.

\section{Catalase peroxidase was upregulated}

\section{in $V$. longisporum as a response to $B$. napus xylem sap.}

Spot number U1 was upregulated in the proteomic analysis when $V$. longisporum was treated with xylem sap from its host plant, $B$. napus. It was found to increase more than twofold in the xylem-sap-treated fungal proteome (Fig. 3C). It was confidently identified as the enzyme catalase peroxidase (NCBI accession number CAC59821) encoded by cpeA in A. nidulans by the TURBOSequest analysis, because two tryptic peptides with $\mathrm{X}$-corr value of 4.75 and 3.03 highly matched with the theoretical spectra (Table 1). The cpeA gene in A. nidulans encodes an $81-\mathrm{kDa}$ bifunctional enzyme, catalase peroxidase that has a conserved motif for heme coordination (Scherer et al. 2002). In A. nidulans, three monofunctional catalases have been described and the cpeA gene product was first observed as a fourth catalase activity in native polyacrylamide gel, and named catalase D (Cat D) (Kawasaki and Aguirre, 2001). Cat $\mathrm{D}$ activity was induced by glucose starvation, high temperature, and $\mathrm{H}_{2} \mathrm{O}_{2}$ treatment.

A cDNA library of $V$. longisporum was used to obtain the sequences of candidate genes (Singh et al. 2010). The MS2 spectrum of catalase peroxidase (spot U1) was used to search for matches against the cDNA library sequences, and two cDNA clones from the library matched peptides for confident identification of the protein spot. These two clones were sequenced fully and, subsequently, the full sequence of $V$. longisporum catalase peroxidase was obtained.

The $V$. longisporum catalase peroxidase coding region comprises an open reading frame of 2289 bp (Supplementary Fig.

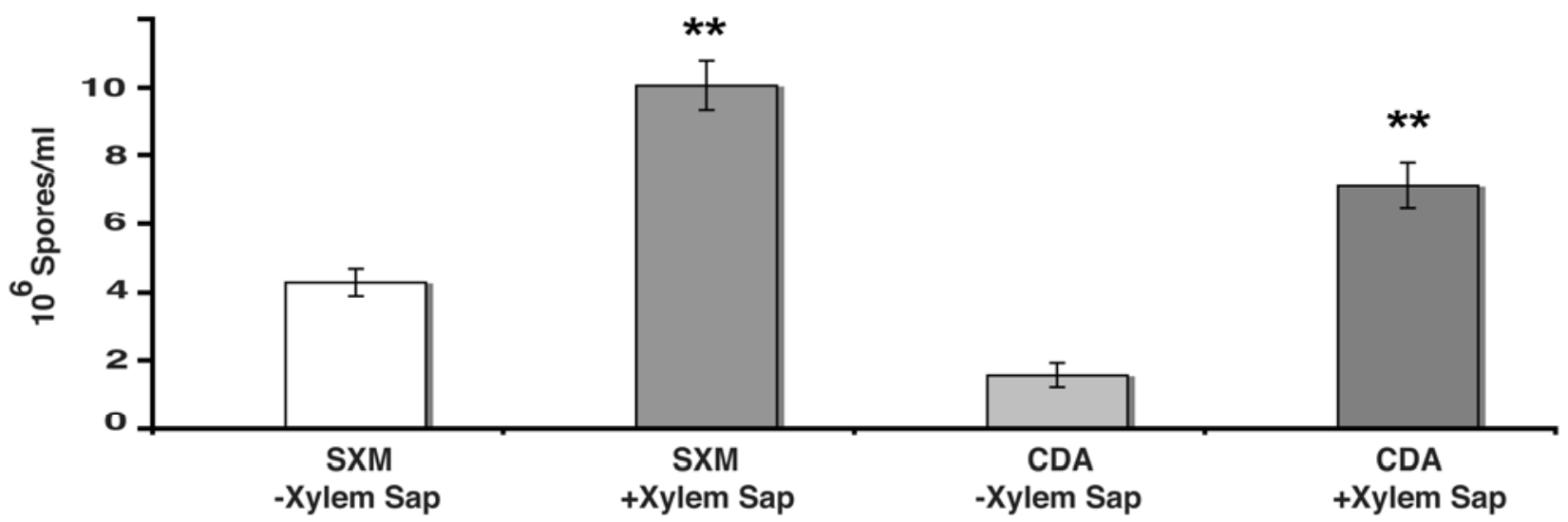

Fig. 2. Influence of filtered xylem sap on Verticillium longisporum growth, development, and spore formation. The number of V. longisporum spores per milliliter from each growth condition was analyzed 8 days after inoculation. Data indicate means $(n=3) \pm$ standard deviation. Significant differences between samples are illustrated by asterisks (*** and ** indicate $P \leq 0.001$ and 0.01 , respectively). 


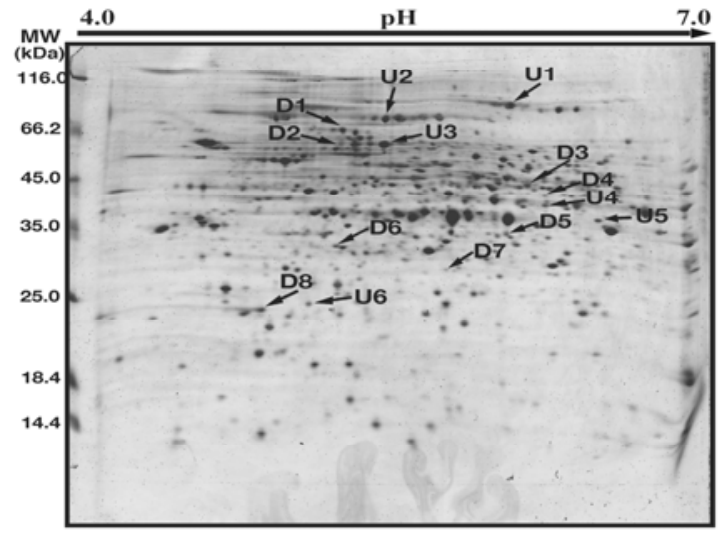

B

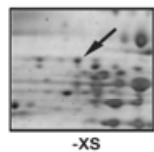

-xS

D2 Unidentified

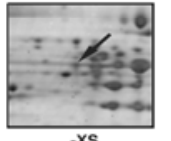

D3 Ketol-acid reductoisomerase
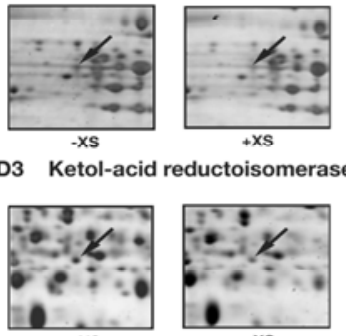

-xs

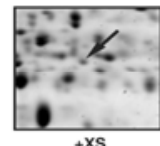

D4 Aflatoxin aldehyde reductase
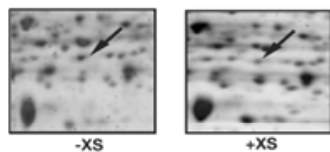

D5 NADPH oxidoreductase
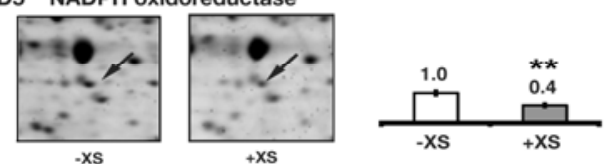

D6 Adenine
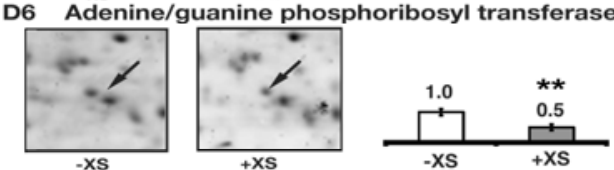

D7 Unidentified
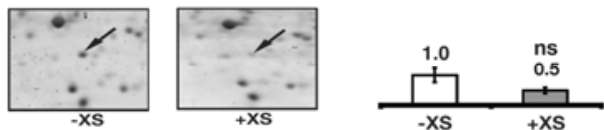

D8 Translation initiation factor 5A, elF-5A
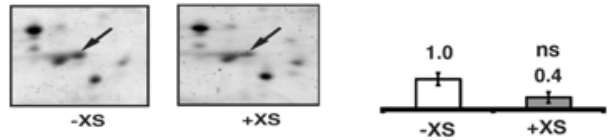

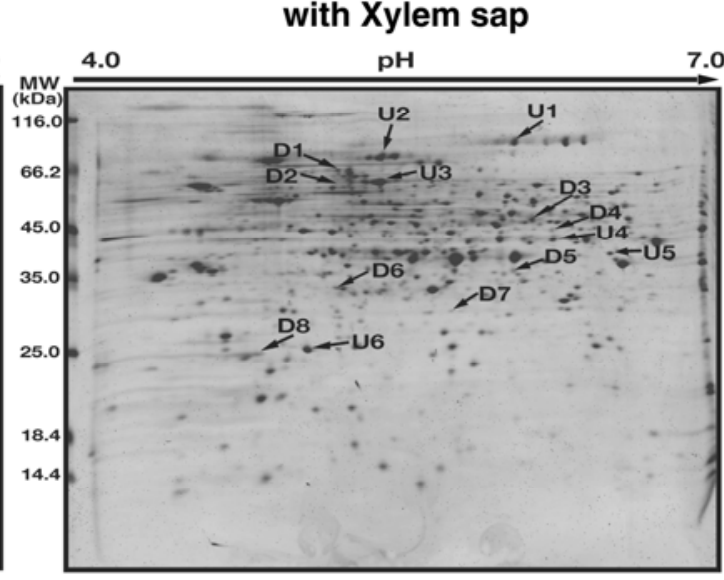

C U1 Catalase-peroxidase
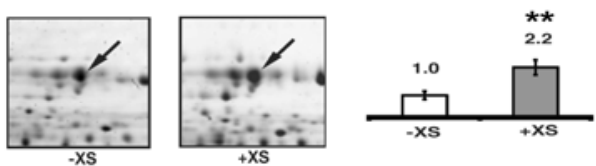

U2 Heat-shock protein, hsp70
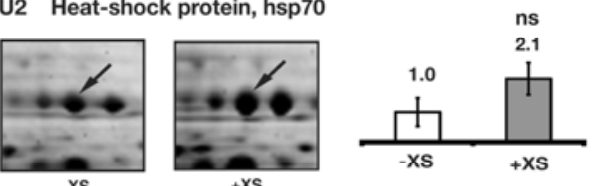

U3 Heat-shock protein, hsp60
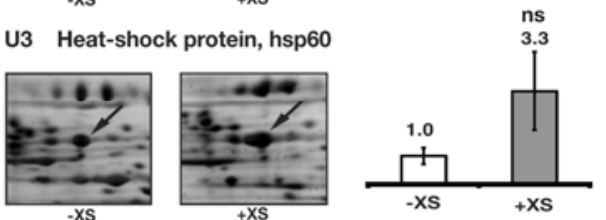

U4 Coproporphyrinogen III oxidase
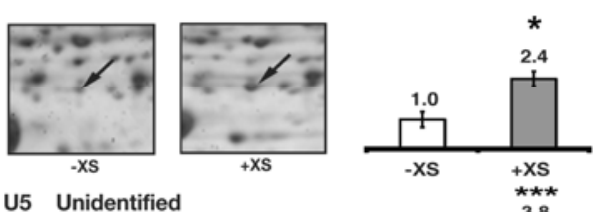

U5 Unidentified

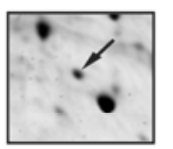

-xs
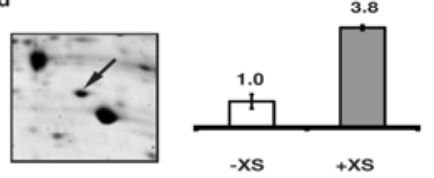

U6 Unidentified

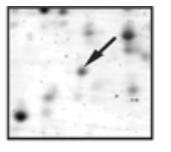

-xs
$+\mathrm{XS}$

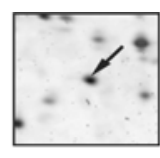

$+\mathrm{XS}$

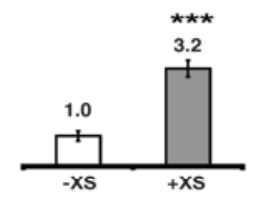

Fig. 3. Differential proteome of Verticillium longisporum induced by xylem sap. A, Two-dimensional (2-DE) gels of the V. longisporum proteome untreated or treated with xylem sap from rapeseed. These are representative figures from three biological and two technical replicates of each condition. Differentially expressed proteins are marked with arrows and labeled: U1-U6 = upregulated protein spots and D1-D8 = downregulated protein spots. Close-up views of the regions of the 2-DE gels that show significant $\mathbf{B}$, downregulation or $\mathbf{C}$, upregulation in protein expression (untreated [-XS] versus treated [+XS] with xylem sap from rapeseed). Arrowheads indicate the differentially expressed proteins. Expression histograms show the differential protein expression of $V$. longisporum due to treatment with xylem sap from rapeseed (right). The same scale was used on the y-axis for depicting mean protein spot quantity for all the protein spots. Bars represent mean protein spot quantity of the $V$. longisporum proteome untreated $(-X S)$ versus treated $(+X S)$ with xylem sap. Data indicate means $(n=6) \pm$ standard deviation. Significant differences between the proteins concentrations are illustrated by asterisks $(* * *, * *$, and $*$ indicate $P \leq 0.001$, 0.01 , and 0.05 , respectively; ns indicates $P \geq 0.05$ ). 
S1) which encodes a protein of 762 amino acids with a predicted molecular mass of $83.54 \mathrm{kDa}$. Two isogenes were cloned and the coding sequences showed $98 \%$ identity. $V$. longisporum catalase peroxidase is almost identical (98\% identity) to the protein of $V$. dahliae, one of its proposed parental species (Supplementary Fig. S2). It has high sequence similarity with A. nidulans CpeA protein (70\% identity), to which this protein spot (spot number U1) was found homologous during identification of protein spots in the proteomic analysis. V. longisporum protein also shows high sequence similarity with catalase peroxidase proteins from the phytopathogenic fungus $M$. grisea (74\% identity) and even from the bacterium Flavobacterium johnsoniae (71\% identity).

In the in-gel catalase activity assay, equal amounts of the native protein from $V$. longisporum and $V$. longisporum treated with xylem sap were run on a native gel. Two clear bands were observed in each sample against a dark background after stain- ing for catalase activity (Fig. 4A). After quantification of the activity, it was found that the catalase activity has increased significantly in the lower band in the sample treated with xylem sap. Hence, the xylem sap causes an increase in the specific catalase activity in accordance with the result from the 2D-PAGE analysis, where it is upregulated. A second catalase activity was unaffected by the addition of xylem sap (Fig. 4A).

$V$. longisporum has been described as a "near-diploid" organism (Inderbitzin et al. 2011; Karapapa et al. 1997), prompting us to ascertain whether $V$. longisporum catalase peroxidase (Vlcpe)A-1 had an isogene. Therefore, $V$. longisporum and $V$. dahliae genomic DNA was digested with different restriction enzymes and subjected to Southern hybridization. A specific and fully sequenced VlcpeA- 1 fragment from $V$. longisporum was used as the probe. In several independent Southern hybridization analyses, two signals were generated for $V$. longisporum compared with $V$. dahliae for the genomic DNA digested with

Table 1. Homologies of differentially expressed proteins of Verticillium longisporum after treatment with xylem sap from Brassica napus

\begin{tabular}{|c|c|c|c|c|c|c|c|}
\hline Spot $^{\mathrm{a}}$ & Protein & Organism & $\mathbf{N C B I}^{b}$ & $\begin{array}{c}\text { MWe/ } \\
\text { pIe }^{\mathrm{c}}\end{array}$ & Matched peptides & $X$-corr ${ }^{d}$ & $\begin{array}{c}\text { Coverage } \\
(\%)^{\mathrm{e}}\end{array}$ \\
\hline U1 & Catalase peroxidase & Aspergillus nidulans & CAC59821 & $90 / 6.1$ & FLENPDQFADAFAR SPAGAHQYVAK & 4.75 & 3.38 \\
\hline \multirow[t]{3}{*}{$\mathrm{U} 2$} & Heat shock protein 70 & Neurospora crassa & XP_961753 & $78 / 5.4$ & STNGDTHLGGEDFDIHLVR & 5.73 & 9.30 \\
\hline & & & & & MLGNFQLVGIPPAHR & 4.4 & \\
\hline & & & & & MKETAESFLSKPVK & 4.09 & \\
\hline \multirow[t]{9}{*}{ U3 } & Heat shock protein 60 & N. crassa & XP_956500 & $60 / 5.5$ & TNEVAGDGTTSATVLAR & 6.17 & 20.73 \\
\hline & & & & & VEFEKPLILLSEK & 4.46 & \\
\hline & & & & & FVDALNATR & 4.17 & \\
\hline & & & & & TIIENAGLEGSVVVGK & 3.75 & \\
\hline & & & & & AAVEEGILPGGTALIK & 3.49 & \\
\hline & & & & & NVAAGCNPMDLR & 3.36 & \\
\hline & & & & & AIFSETVKNVAAGCNPMDLR & 2.95 & \\
\hline & & & & & GQLQVAAGCNPMDLR & 2.88 & \\
\hline & & & & & LSGGVAVIK & 2.56 & \\
\hline \multirow[t]{3}{*}{ U4 } & Copropor phyrinogen III & & & & & & \\
\hline & oxidase & Verticillium dahliae & BQ111120 & $43 / 6.2$ & GGVGVSVVYGGTLPK & 4.16 & 2.76 \\
\hline & & & & & YVEFNLVHDR & 3.25 & \\
\hline \multirow[t]{4}{*}{ D1 } & Vacuolar membrane & & & & & & \\
\hline & $\begin{array}{l}\text { ATPase catalytic } \\
\text { subunit A }\end{array}$ & V. dahliae & BQ110481 & $66 / 5.2$ & LGEMPADQGFPAYLSAK & 4.39 & 22.60 \\
\hline & & & & & TTLIANTSNMPVAAR & 4.29 & \\
\hline & & & & & DQGLDVAMMADSSSR & 3.56 & \\
\hline \multirow[t]{4}{*}{ D3 } & Ketol-acid & & & & & & \\
\hline & precursor & N. crassa & XP_961335 & $46 / 6.2$ & NDTLALIGYGSQGHGQGLNLR & 3.89 & 13.18 \\
\hline & & & & & VEVPTDVDVILVAPK & 3.02 & \\
\hline & & & & & NLFDVDEAISR & 2.99 & \\
\hline \multirow[t]{3}{*}{ D4 } & Aflatoxin aldehyde & & & & & & \\
\hline & reductase & V. dahliae & BQ110032 & $45 / 6.2$ & IILGLMTFGPSESDGAR & 4.02 & 9.37 \\
\hline & & & & & ATPFAETLEALDK & 3.15 & \\
\hline \multirow[t]{6}{*}{ D5 } & NADPH oxidoreductase & & & & & & \\
\hline & & V. dahliae & BQ110643 & $38 / 6.1$ & SALAGIDAVVSTLGAPAVGEPQR & 5.39 & 27.70 \\
\hline & & & & & NLVEAAVEAGVQR & 4.47 & \\
\hline & & & & & VKEVVVDYNDPASLK & 4.21 & \\
\hline & & & & & EVVVDYNDPASLK & 3.49 & \\
\hline & & & & & IKTEELLVEK & 3.14 & \\
\hline \multirow[t]{6}{*}{ D6 } & Hypothetical protein & & & & & & \\
\hline & $\begin{array}{l}\text { AN9083.2 (conserved } \\
\text { domain: Adenine }\end{array}$ & & & & & & \\
\hline & & & & & & & \\
\hline & transferase) & A. nidulans & XP_682352 & $34 / 5.2$ & $\begin{array}{l}\text { VLIVDDIIATGGSAK } \\
\text { GFLFGPGLALR }\end{array}$ & $\begin{array}{l}4.98 \\
3.44\end{array}$ & 8.85 \\
\hline & & & & & LPGPCVTAEYQK & 3.12 & \\
\hline & & & & & EYGTDFFQMQEDAIKPGQK & 2.58 & \\
\hline \multirow[t]{4}{*}{ D8 } & Translation initiation & & & & & & \\
\hline & factor eIF-5A & V. dahliae & BQ110791 & $25 / 4.9$ & KLEDLSPSTHNMDVPNVTR & 4.31 & 12.20 \\
\hline & & & & & VHIVATDIFTGK & 3.57 & \\
\hline & & & & & LEDLSPSTHNMDVPNVTR & 3.52 & \\
\hline
\end{tabular}

\footnotetext{
${ }^{\text {a }}$ Spot numbers. U1 to U4: upregulated protein spots and D1 to D8 = downregulated protein spots.

${ }^{\mathrm{b}}$ National Center for Biotechnology Information (NCBI) accession number.

${ }^{\mathrm{c}} \mathrm{MWe} / \mathrm{pIe}=$ molecular weight $(\mathrm{kDa})$ and isoelectric point of differentially expressed proteins determined experimentally.

${ }^{\mathrm{d}}$ Cross-correlation scores of matched peptides (TURBOSequest).

e Sequence coverage (percent amino acids).
} 
ApaI and HindIII (Fig. 4B). We also confirmed this result by using the VlcpeA-1 fragment from $V$. dahliae as the probe (data not shown). These results demonstrated that VlcpeA-l has an isogene, VlcpeA-2.

\section{VLCPEA isogenes were silenced up to $80 \%$ \\ by RNA-mediated gene silencing.}

RNA-mediated gene silencing has been successfully implemented in several fungi for targeted gene silencing instead of a conventional knockout (Nakayashiki 2005). The plasmid pME3928 (for details on plasmid construction, discussed below) includes the hairpin construct for silencing of VlcpeA and the hygromycin resistance gene as selective marker. Agrobacterium tumefaciens-mediated transformation of $V$. longisporum was applied and 30 independent hygromycin-B-resistant transformants were selected at random for further analysis. The extent of VlcpeA silencing was monitored by reverse-transcription polymerase chain reaction (RT-PCR) because the silencing of gene expression is the result of posttranscriptional degradation of targeted mRNA. Total RNA was extracted from the VlcpeA silenced mutant (VlcpeAsm) and the wild type. RNA was extracted for each strain three times from independent cultures. RT-PCR results showed the significant knockdown of VlcpeA transcripts (Fig. 5A). The degree of silencing of catalase peroxidase genes was estimated by RT-PCR by the ratio of the amplification of VlcpeA between the respective transformants and the unsilenced wild type. For each transformant, three biological replicates were analyzed. High-frequency silencing was observed for $71 \%$ of the transformants exhibiting reduced gene expression. The extent of silencing varied in the different transformants between high and moderate levels. After $42 \mathrm{dpi}$ in planta, the silencing of the VlcpeA isogenes was still stable (Fig. 5B).

\section{Silencing of VlcpeA does not affect the saprophytic growth phenotype but results in $\mathrm{H}_{2} \mathrm{O}_{2}$-sensitive mutants of $\mathrm{V}$. longisporum.}

We analyzed the growth behavior of the silenced mutants compared with that of $V$. longisporum on different media. The strains were plated on CDA and SXM and incubated at $25^{\circ} \mathrm{C}$ for several days after $48 \mathrm{~h}$ and, thereafter, each day, the diame-
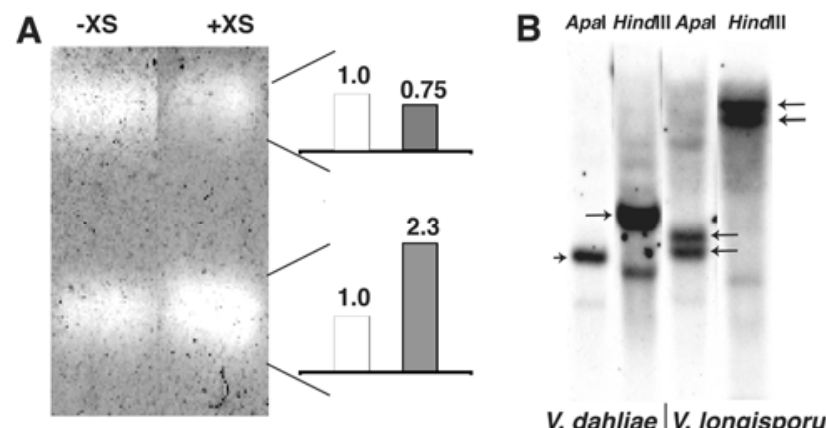

Fig. 4. Verticillium longisporum catalase peroxidase isoproteins and encoding isogenes. A, In-gel catalase assay. Equal amounts $(10 \mu \mathrm{g})$ of protein extracts from $V$. longisporum untreated $(-\mathrm{XS})$ or treated $(+\mathrm{XS})$ with xylem sap of Brassica napus were separated in native polyacrylamide gel and stained for catalase activity according to Zou and associates (2000) Catalase activities appear as clear bands in the dark-green background Relative intensity of the catalase activities in each extract was determined using Kodak Molecular Imaging software (right). The experiment was repeated several times and the standard deviation did not exceed $25 \%$. B, Southern hybridization. Determination of two copies of $V$. longisporum catalase peroxidase (VlcpeA) by Southern hybridization analysis of $V$. dahliae and $V$. longisporum. The genomic DNA was digested with ApaI and HindIII. A 402-bp sequence of VlcpeA-1 was used as a probe. Arrows indicate the signal generation by probe binding. ter of the colony was measured and noted (data not shown). The colonies were investigated (dissection microscope) to detect differences between the mutant and wild type. From these analyses, no differences could be observed. The growth phenotype of the VlcpeA-silenced mutant is the same as the wild type.

For comparison, the mutants silenced in VlcpeA were grown on CDA plates supplemented with different substances inducing oxidative and redox-membrane stress such as $\mathrm{H}_{2} \mathrm{O}_{2}$, menadione, ethanol, and sodium dodecyl sulfate (SDS) in different concentrations. $\mathrm{H}_{2} \mathrm{O}_{2}$ inhibited growth of $\mathrm{V}$. longisporum in silenced mutants dramatically (Fig. 5C). At a concentration of
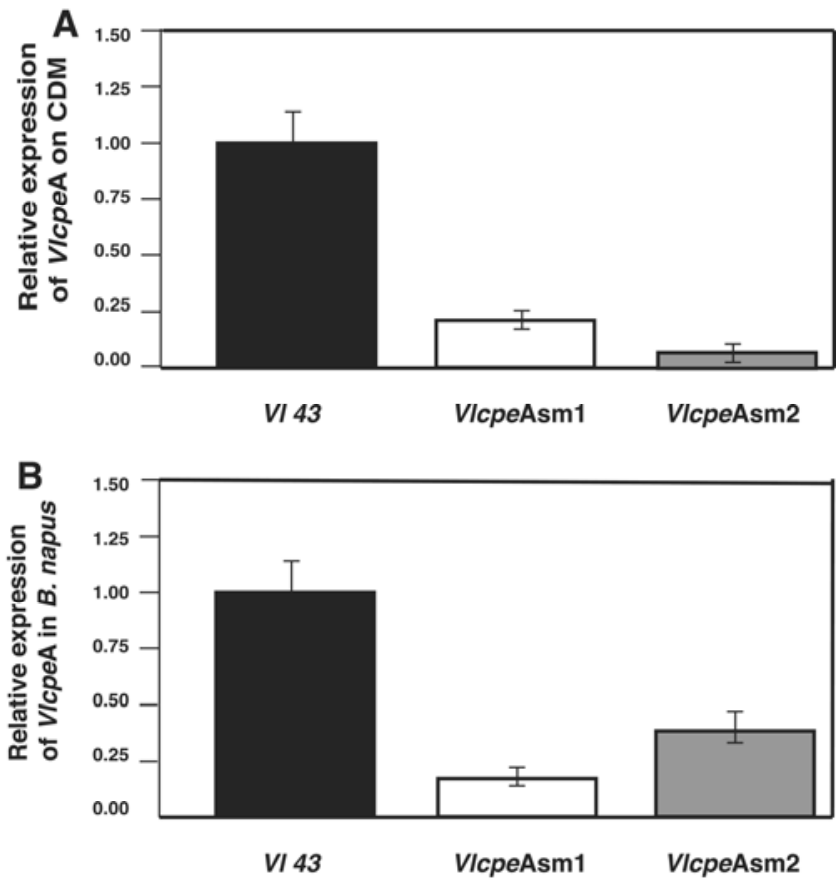

C

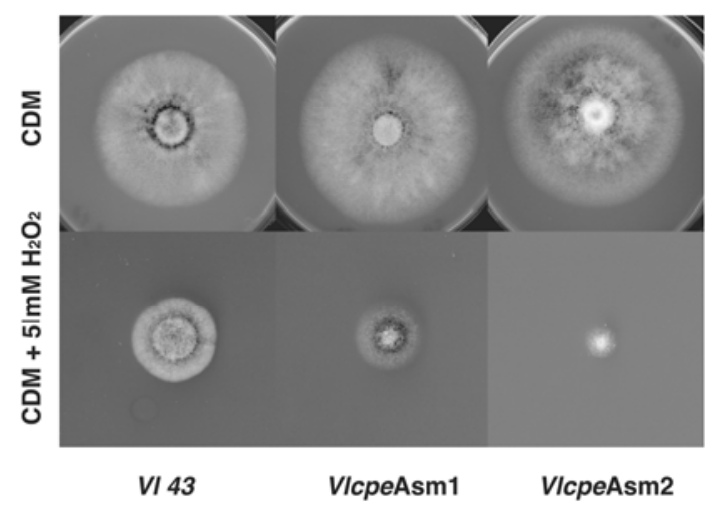

Fig. 5. Expression of catalase peroxidase-encoding genes of Verticillium longisporum. A, Relative expression of $V$. longisporum catalase peroxidase (VlcpeA) in wild type ( $V l ~ 43)$ and silenced mutant (VlcpeAsm) measured by quantitative real-time polymerase chain reaction (PCR). RNA was extracted from three independent cultures. VlcpeA cDNA was normalized to the histone cDNA. VlcpeAsm 1 and VlcpeAsm $2=$ cpeA silenced mutants. Error bars represent the standard deviation of four different measurements of cDNA. B, Relative expression of VlcpeA in Brassica napus measured by quantitative real-time PCR 42 days postinfection. VlcpeA cDNA was normalized to the histone cDNA. cDNA from host plants mock inoculated with water served as control. $V l 43=$ cDNA from B. napus infected with the wild type; VlcpeAsm 1 and VlcpeAsm $2=\mathrm{cDNA}$ from B. napus infected with VlcpeA-silenced mutant. Error bars represent the standard deviation of triplicates. C, Test for VlcpeAsm sensitivity to $\mathrm{H}_{2} \mathrm{O}_{2}$. $V l 43$ and VlcpeA-silenced mutants were cultivated on Czapek Dox agar

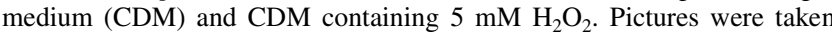
after 4 days of growth. 
$5 \mathrm{mM} \mathrm{H} \mathrm{H}_{2}$, the silenced mutants of VlcpeA were strongly reduced in growth. At higher concentrations of $\mathrm{H}_{2} \mathrm{O}_{2}$ (approximately $10 \mathrm{mM}$ ), the growth behavior of the wild type was also affected. Menadione and SDS did not affect growth of the wild type or the mutant fungi, whereas ethanol inhibited all tested fungi equally.

\section{Late-stage plant symptoms decrease significantly} during infection in the silenced mutant versus the wild type.

We analyzed whether VlcpeAsm mutants were still able to colonize B. napus and cause disease symptoms similar to the wild-type strain (Fig. 6). Two different sets of disease symptoms can be observed during the infection of oilseed rape by $V$. longisporum: the host plant becomes stunted and shows signs of early senescence. Both symptoms are normally visible after $21 \mathrm{dpi}$ and are more pronounced at later time points. Oneweek-old $B$. napus seedlings were infected by root dip inoculation to compare the severity of the disease; height and the signs of early senescence (disease scores) of the plants were measured weekly postinoculation until 35 dpi.

Scoring of the disease symptoms corroborated the requirement of full catalase peroxidase function for plant pathogenicity. The infected rapeseed plants were scored for disease symptoms by assigning disease scores from 1 to 9 corresponding to asymptomatic to dead plants (Eynck et al. 2007). The plants were observed once a week and, in the assessment of the symptoms, the yellowing and death of the leaves were considered. Disease scores of the mock-infected plants of greater than 1 reflect the yellowing of leaves due to natural senescence. Disease symptoms were visible at $21 \mathrm{dpi}$ and grew more pronounced at 35 dpi (Fig. 6B). Both VlcpeAsm and the wild type showed similar disease scores only in the initial phase of the disease at 21 and 28 dpi. At $35 \mathrm{dpi}$, the disease score of the VlcpeAsminfected plants (4.5) was lower than the plants infected with wild-type fungus (5.5) but still significant compared with mockinoculated control plants (3.7) (Fig. 6B). This reflects a slow down of the disease of the plant when infected by the mutant fungi, corroborating a reduced impact on senescence.

Similar observations for the stunting symptom support this finding. Stunting was barely visible after 21 dpi but became pronounced after $28 \mathrm{dpi}$ for VlcpeAsm and the wild type. Consistent with the lowered senescence, the effect on stunting of the plant was significantly less pronounced at 35 dpi (Fig. 6A).

The DNA content was determined in a time window of 35 and 42 dpi where there were no differences within the respec- tive sets of experiments $\left(P_{(\text {time })}>0.5\right)$. Very low concentrations of fungal DNA were found in roots (2 to $3.5 \mathrm{ng} / \mathrm{g}$ fresh weight [FW]) and did not vary between mock-inoculated and $V l$ 43-, VIcepA1-, and VlcpeA2-infected plants (Fig. 7). However, in the hypocotyls where the highest concentration of fungal DNA (65 to $110 \mathrm{ng} / \mathrm{g} \mathrm{FW}$ ) was present, there were pronounced differences between plants infected with wild-type strain $V l 43$ or the silenced strain VlcpeAsm (Fig. 7). Fungal DNA was significantly lower in stems (14 to $18 \mathrm{ng} / \mathrm{g} \mathrm{FW}$ ) than in the hypocotyl. These data suggest that the mutant strain is able to perform the initial colonization of the plant but has some difficulties in the hypocotyl of the plant (Fig. 7).

The mutant fungi were isolated from the plants and it was verified that they were still silenced. This suggests that the catalase peroxidase which is already induced in the fungus by diluted plant xylem sap represents an alert reaction because significant expression is only essential for later stages of plant infection but not required for the induction of diseases symptoms.

\section{DISCUSSION}

The composition of the xylem sap depends on several factors such as age, plant variety, or nitrogen supply (Tilsner et al. 2005; Zornoza et al. 1996) and includes water, inorganic salts, sugars, and some organic compounds which can act as nutrients (Schurr and Schulze 1995). In the xylem, water and inorganic nutrients are translocated from roots to the aerial plant organs. The xylem sap also provides a medium for cross-talk between the pathogen, $V$. longisporum, and its host, $B$. napus. Accordingly, colonization of xylem vessels of the host plant provides the vascular phytopathogen $V$. longisporum with a combination of stimulating substances, including nutrients and, presumably, signal molecules and inhibitory compounds involved in plant defense. The presence of xylem sap even without the plant primarily inhibited fungal growth. The stimulating effect of xylem sap on fungal growth could only be measured when xylem sap was filtered and, therefore, inhibitory compounds were removed.

Xylem sap without macromolecules stimulated mycelial growth of the fungus, earlier bud spore formation, and significantly more conidia. This is presumably due to signal molecules because a 10-fold dilution of the filtered xylem sap resulted in the same stimulation of fungal growth and development. This might be due to molecules that boost the growth of $V$. longis-
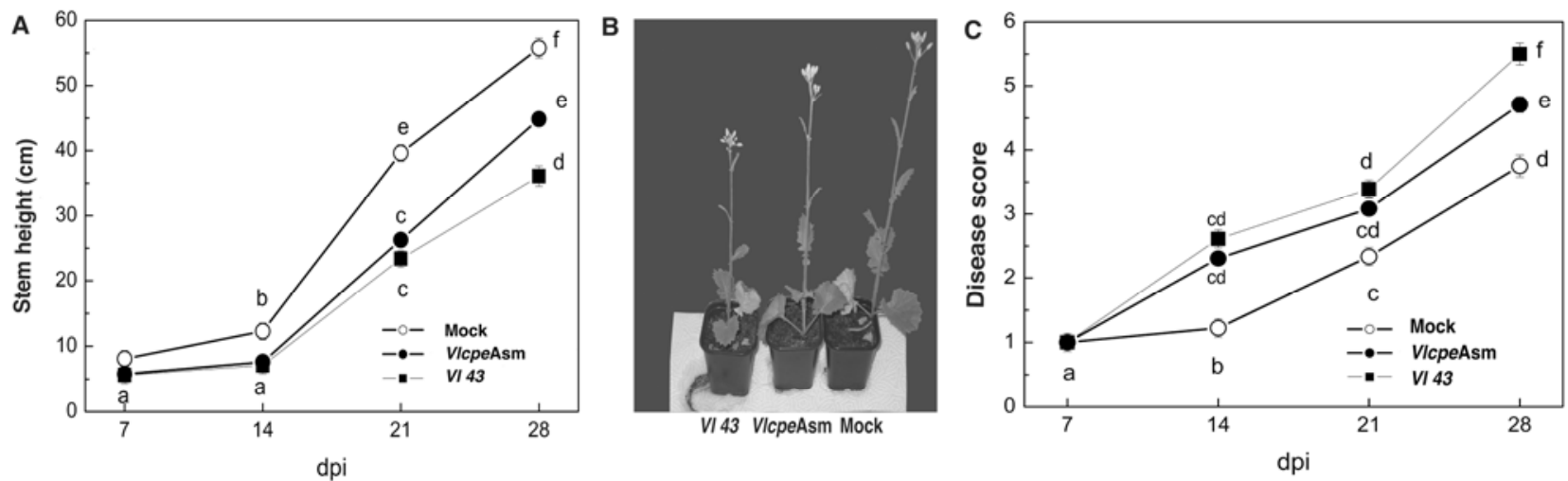

Fig. 6. Assessment of pathogenicity of the Verticillium longisporum catalase peroxidase-silenced mutant (VlcpeAsm). A, Assessment of stunting of rapeseed due to $\mathrm{V}$. longisporum infection. The height of 20 replicates each of rapeseed plants infected with the wild type (Vl 43 ) and $V l c p e$ Asm was measured at 7,14 , 21 , and 28 days postinfection (dpi). For comparison, the height of rapeseed plants mock inoculated (mock) with tap water was also measured. Different letters indicate significant differences at $P<0.05$. The plants are heavily infected at 28 dpi. Data represent average \pm standard deviations of 20 experimental replicates. B, Stunting and disease development in Brassica napus infected with either Vl 43, VlcpeAsm, or mock after 28 dpi. C, Assessment of disease development by scoring for disease symptoms according to Eynck and associates (2007). Plants were scored for disease symptoms at 7 , 14, 21 , and 28 dpi. Data represent average \pm standard deviations of 20 experimental replicates. 
porum even when present in low concentrations. When the bacterial vascular pathogen Xylella fastidiosa was subjected to xylem fluids with varying chemistries, highly significant differences in planktonic growth and biofilm formation were correlated to the concentration of citric acid, amino acids, and inorganic ions in the xylem fluids (Andersen et al. 2007). The enhanced melanization in the presence of xylem sap might be explained by the utilization of tryptophan present in the xylem sap of B. napus (Kehr et al. 2005), resulting in melanin production. This might reflect a $V$. longisporum response to the presence of defense-related proteins in xylem sap (Kehr et al. 2005), because melanized fungi are less susceptible to host defense mechanisms (Taborda et al. 2008).

The observation that B. napus xylem sap affected $V$. logisporum growth and development implies that the fungus might be perceiving the plant, and that this perception could be manifested by differential protein expression in $V$. longisporum. Host extracts also changed protein expression patterns of the phytopathogenic bacteria Dickeya dadantii (Babujee et al. 2007) and Pectobacterium atrosepticum (Mattinen et al. 2007). Our proteomic analysis revealed alterations of protein expression for only 14 protein spots among more than 800 fungal spots upon treatment with xylem sap.

The six upregulated proteins are mainly related to oxidative stress response. Upregulation of the analyzed catalase peroxidase was the most prominent statistically relevant effect and might be a consequence of encountering oxidative stress. Germin proteins constitutively present in the xylem sap as well as in leaf apoplast might be possible candidates to evoke this response (Kehr et al. 2005) because some of them can generate $\mathrm{H}_{2} \mathrm{O}_{2}$. Indeed, increased $\mathrm{H}_{2} \mathrm{O}_{2}$ levels and diminished Verticillium spp. growth were detected in Arabidopsis thaliana overexpressing germin-like protein GLP1 from $B$. oleracea (Knecht et al. 2010). The catalase peroxidase detected in our study is a close homologue to a bifunctional catalase peroxidase in Aspergillus nidulans that is encoded by cpeA and car- ries a conserved motif for heme coordination (Scherer et al. 2002). A further upregulated protein homologous to coproporphyrinogen III oxidase from $V$. dahliae might be co-regulated with catalase peroxidase, because it is an essential enzyme to catalyze the sixth step of heme biosynthetic pathway (Lash et al. 1999). The proteins homologous to heat-shock protein 70 (hsp70) and heat-shock protein 60 (hsp60) from N. crassa were also upregulated. Transcripts for hsp60 and hsp70 were also upregulated in the plant pathogen Phytophthora infestans during early stages of potato infection (Avrova et al. 2003). Hsp60 can protect Saccharomyces cerevisiae against oxidative damage due to $\mathrm{H}_{2} \mathrm{O}_{2}$ and superoxide anions (Cabiscol et al. 2002).

In contrast, a putative NADPH oxidoreductase, which is also known to be involved in redox reactions, was one of the eight downregulated proteins of our proteome analysis. NADPH oxidoreductases accumulate rapidly in Arabidopsis plants under various oxidative stress conditions and have been reported to be involved in $\mathrm{NAD}(\mathrm{P}) / \mathrm{NAD}(\mathrm{P}) \mathrm{H}$ homeostasis (Babiychuk et al. 1995) and even iron uptake (Roman et al. 1993). The downregulated putative subunit of a vacuolar proton-translocating ATPases (V-ATPases) might also reflect that the xylem sap has an oxidizing environment. This protein is part of a complex which acidifies organelles of the vacuolar network, including the vacuoles, Golgi apparatus, or other secretory vesicles (Forgac 1989). Reducing agents have a stabilizing effect on the V-ATPase (Dschida and Bowman 1995), and oxidizing agents like $\mathrm{H}_{2} \mathrm{O}_{2}$ are potent inhibitors of the V-ATPase in vitro.

Four proteins involved in biochemical processes are downregulated by xylem sap. They include the eukaryotic initiation factor eIF-5A, involved in translation (Hershey 1991), and a putative aflatoxin, B1 aldehyde reductase (Judah et al. 1993). Another downregulated protein carries an adenine phosphoribosyl transferase conserved domain. It has been shown that the phosphoribosyl transferase activities have a positive effect on

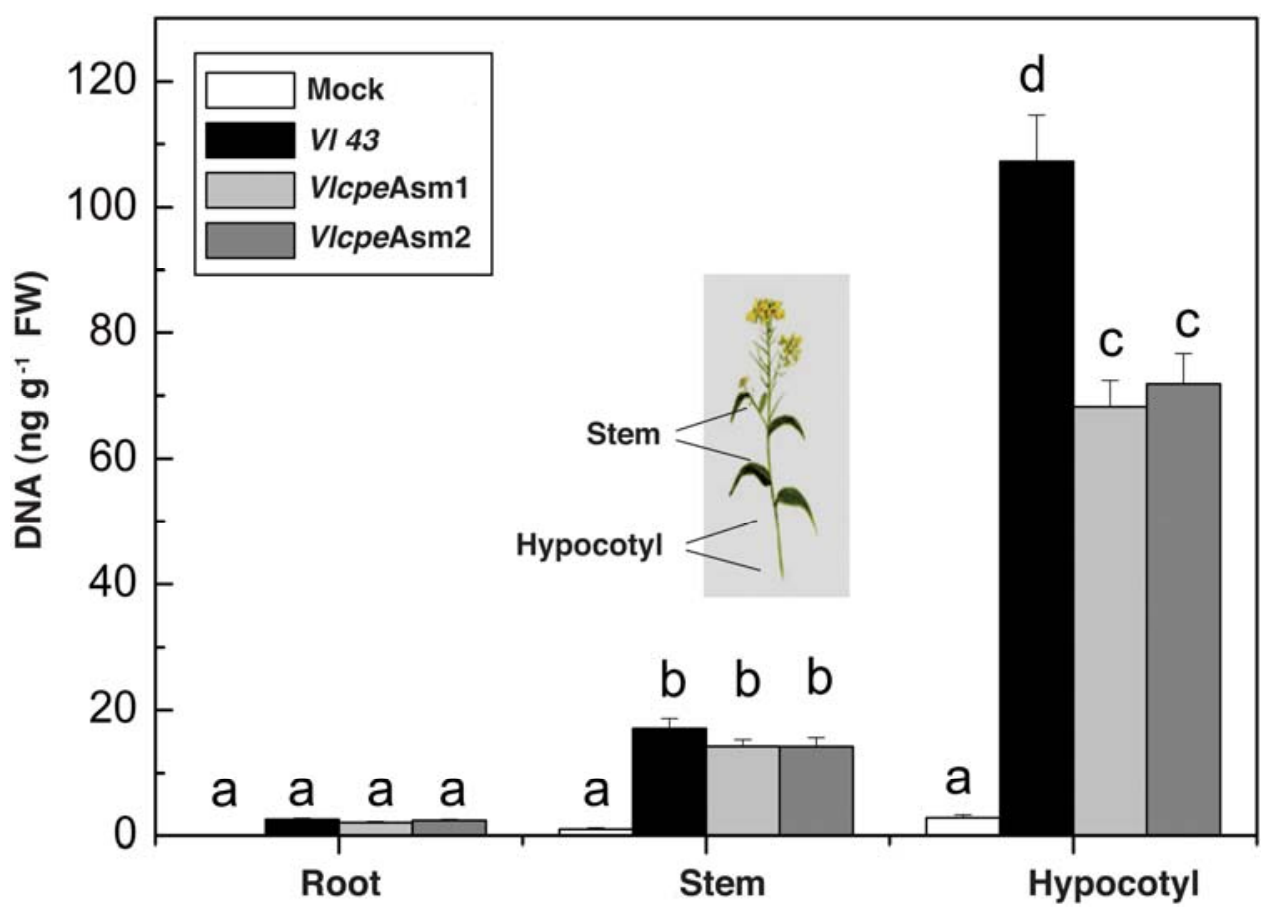

Fig. 7. Determination of the Verticillium longisporum DNA concentration in infected plant tissues. Different letters (a to d) indicate significant differences at $P<0.05$. V. longisporum DNA was measured with real-time polymerase chain reaction days postinfection in stems, hypocotyls, and roots of Brassica napus inoculated with $V$. longisporum catalase peroxidase-silenced mutants (VlcpeAsm) and the wild type (Vl 43 ) at 42 days postinfection. Data represent average \pm standard deviations of five experimental replicates. Mock-inoculated plants as a control did not show presence of any $V$. longisporum DNA; ng Vl DNA/g $\mathrm{FW}=$ nanograms of $V$. longisporum DNA per gram fresh weight of plant tissue. 
the rate of external purine uptake by Schizosaccharomyces pombe cells. The fourth downregulated protein is a precursor of ketol-acid reductoisomerase as part of branched chain amino acid biosynthesis. Ketol-acid reductoisomerase expression is also downregulated following host penetration during infection of potato by $P$. infestans (Grenville-Briggs et al. 2005). This could be due to a ready access of amino acids from the plant.

The function of the upregulated catalase peroxidase identified by this proteomic approach was analyzed in more detail to reveal whether this approach is suitable to identify diseaserelated proteins of the fungus. Plants normally resist pathogen attacks or delay pathogen growth by triggering defense responses, including the production of ROS such as $\mathrm{H}_{2} \mathrm{O}_{2}$, superoxide radicals, or hydroxyl radicals ( $\mathrm{Lu}$ et al. 2006). A rapid response upon perception of microbial pathogens termed oxidative burst can be followed by a second ROS burst during plant-pathogen interactions triggering hypersensitive cell death (Lamb and Dixon 1997). Catalase peroxidase can protect a fungal pathogen by decomposing the hydrogen-peroxide generated by the host (Wysong et al. 1998). Catalases and peroxidases of phytopathogenic fungi have attracted attention as potential virulence factors (Garre et al. 1998; Nathues et al. 2004). Silencing of catalase peroxidase reduced growth of the fungus in the hypocotyl, supporting the function as a potential virulence factor in the infection of rapeseed. ROS might play an essential role in the hypocotyl and are possibly preventing the fast spreading of the fungus to other parts of the plant. Alternatively, the catalase peroxidase could also be important to support fungal development in the plant. ROS have been shown to be important developmental signals for fungal differentiation and nutrient scavenging (Egan et al. 2007; Nahlik et al. 2010; Scott and Eaton 2008). The exact role of the fungal catalase peroxidase isogene pair and also whether there are different functions of both isogenes will be an interesting future question.

Cloning and sequencing of both isogenes for catalase peroxidase revealed a $98 \%$ identity to the corresponding protein in $V$. dahliae, one of its parental species. It was also found to be 70 to $74 \%$ identical to the corresponding proteins in the fungi $A$. nidulans or $M$. grisea and the bacterium $F$. johnsoniae. VICPEA belongs to the KatG catalase peroxidases in class I of the plant peroxidase superfamily because it contains the three motifs SQXWWPADXGXY, AXXMGLIYVN, and GXXPXX AXXEXQGLGW, which are conserved in all KatG catalase peroxidases (Zamocky et al. 2001). V. longisporum has been described as near diploid or amphihaploid, with at least one parent as V. dahliae (Barbara et al. 2005; Karapapa et al. 1997). Southern hybridization analysis as well as cloning and sequencing revealed that there are two isogenes for catalase peroxidase present in $V$. longisporum. In contrast, $V$. dahliae carries only a single gene for cpeA.

In summary, our data have identified the upregulation of catalase peroxidase as the strongest reaction of $V$. longisporum to the presence of xylem sap after inhibitory proteins had been removed. This is presumably an early and maybe even primarily prophylactic reaction to the hostile xylem sap environment. Reduced expression of the enzyme is sufficient to allow the performance of the initial phase of the disease. However, the enzyme is essential for completing the disease, resulting in pronounced stunting and early senescence. It will be interesting to examine whether the enzyme might be a putative target for drugs which reduce the impact of the pathogen on the loss of rape seed crops which is encountered in Europe during the last decades. This proteomic approach is promising and could also be applicable for other plant pathogens to identify diseaserelated proteins.

\section{MATERIAL AND METHODS}

\section{Strains, media, and growth conditions.}

In all, V. longisporum 43 and V. dahliae 73 strains were used in this study (Zeise and von Tiedemann 2002a). SXM (Neumann and Dobinson 2003) contained sodium polypectate ( $2 \mathrm{~g} /$ liter), casein hydrolysate (4 g/liter), $1 \mathrm{M}$ magnesium sulfate ( $2 \mathrm{ml} / \mathrm{liter}), 50 \times$ AspA solution $(20 \mathrm{ml} / \mathrm{liter})$, and 1,000× trace elements ( $1 \mathrm{ml} / \mathrm{liter})$. CDA contained sucrose (30 g/liter), $1 \mathrm{M}$ magnesium sulfate ( $2 \mathrm{ml} / \mathrm{liter}), 50 \times$ AspA solution (20 $\mathrm{ml} / \mathrm{liter})$, and ferrous sulfate (0.01 g/liter). Czapek Dox medium was inoculated with $V$. longisporum spores and incubated at $25^{\circ} \mathrm{C}$ for 10 days in darkness to generate fungal spore suspension stock. The spores were counted using a hemocytometer, adjusted to $1 \times 10^{6} \mathrm{spores} / \mathrm{ml}$, and preserved as $30 \%$ glycerol stock at $-80^{\circ} \mathrm{C}$.

\section{Xylem sap production.}

Rapid-cycle rape (ACaacc) (Williams and Hill 1986) was used for xylem sap production as described previously (Singh et al. 2010). Uninfected rapeseed plants were harvested when they were 42 days old. For infection, rapeseed plants were inoculated with $V$. longisporum when they were 7 days old and xylem sap was extracted 35 dpi in correspondence to 42-dayold uninfected plants. Xylem sap was also extracted at an additional time point, from 35-day-old rapeseed plant and from corresponding infected rapeseed plants at $28 \mathrm{dpi}$. Xylem sap was filter-sterilized (0.2- $\mu \mathrm{m}$ size; Sarstedt AG, Nümbrecht, Germany) and stored at $-20^{\circ} \mathrm{C}$ until further use.

\section{Impact of xylem sap and xylem sap proteins \\ from $B$. napus on fungal growth.}

To discriminate between the influence of xylem sap and xylem sap proteins on fungal growth, macromolecules larger than $3 \mathrm{kDa}$ were separated from the xylem sap by filtration during a centrifugation step at $4,000 \times g$ for 45 min at $4^{\circ} \mathrm{C}$ (Vivaspin 6, 3000 MWCO; Sartorius, Goettingen, Germany). Then, $100 \mu$ of a spore solution of $1.8 \times 10^{5}$ spores $/ \mathrm{ml}$ was added to $900 \mu \mathrm{l}$ of filtered xylem sap, incubated for 3 days in darkness at $22^{\circ} \mathrm{C}$, and used to determine fungal DNA as described previously (Floerl et al. 2008). Xylem sap proteins were diluted to a concentration of $15 \mu \mathrm{g} \mathrm{ml}^{-1}$. This protein solution $(200 \mu \mathrm{l})$ and $100 \mu \mathrm{l}$ of spore solution $\left(1.8 \times 10^{5}\right.$ spores per milliliter) were added to $700 \mu \mathrm{l}$ of potato dextrose broth (Sigma, Steinheim, Germany) and were grown and used for fungal DNA measurements as described above. Protein concentration was determined using the Coomassie PLUS Assay Kit (Thermo Fisher Scientific, Waltham, MA, U.S.A.) following the manufacturer's instructions.

The impact of filtered xylem sap from rapeseed uninfected or infected with $V$. longisporum on fungal growth and development was analyzed by adding to SXM and CDA in a concentration of 1:7 and 1:70 in warm agar. $V$. longisporum was point inoculated with 5,000 spores in the center of the petri plate. SXM and CDA without added xylem sap and inoculated with $V$. longisporum were taken as controls. The plates were observed by light microscopy using an Olympus SZX12 binocular (Olympus, Hamburg, Germany) or a Zeiss Axiolab light microscope (Zeiss AG, Göttingen, Germany) until 10 days after inoculation. Images were taken using a Kappa PS30 digital camera and the Kappa ImageBase software (Kappa Opto-electronics $\mathrm{GmbH}$, Gleichen, Germany). After 8 days of inoculation, for conidiospore quantification, the agar with the fungus colony was excised with the end of a disposable 1-ml pipette tip (1.0 $\mathrm{cm}$ in diameter) and vortexed for $30 \mathrm{~min}$ in $0.5 \mathrm{ml}$ of physiological solution (Busch et al. 2003; Bussink and Osmani 1998). The number of spores based on three different plates 
was counted from this solution using a hemocytometer. For the cultures used for 2D-PAGE and native gel electrophoresis, $1 \times$ $10^{6}$ conidia of $V$. longisporum were used to inoculate $40 \mathrm{ml}$ of SXM. The fungi were incubated at $25^{\circ} \mathrm{C}$ for 5 days in darkness. After 5 days, sterile-filtered xylem sap, which contains approximately 40 to $50 \%$ less protein than nonfiltered xylem sap, from rapeseed plants uninfected or infected with $V$. longisporum was added in a concentration of 1:7 and incubated for $8 \mathrm{~h}$.

\section{Protein extraction.}

Protein Extraction Reagent (Y-PER-S reagent; Pierce, Rockford, IL, U.S.A.) and protease inhibitor (Complete, protease inhibitor cocktail; Roche Diagnostics, Mannheim, Germany) were added to the powdered fungal mycelium and incubated for $10 \mathrm{~min}$ at room temperature. It was then vortexed and incubated on ice for $20 \mathrm{~min}$, and then centrifuged at 4,500 rpm for $20 \mathrm{~min}$ at $4^{\circ} \mathrm{C}$. The supernatant containing the soluble proteins was collected and stored at $-20^{\circ} \mathrm{C}$. For native protein extraction, cold $50 \mathrm{mM}$ potassium phosphate buffer, $\mathrm{pH} 7.0$ and protease inhibitor were added to the powdered mycelium. It was then centrifuged at $8000 \mathrm{rpm}$ for $15 \mathrm{~min}$ at $4^{\circ} \mathrm{C}$. The supernatant containing the native proteins was collected and stored at $-20^{\circ} \mathrm{C}$ (Chary and Natvig 1989). Protein concentrations were determined using the BCA protein assay kit (Pierce) according to the supplier's manual. The protein used for 2DPAGE experiments was purified by chloroform/methanol extraction (Wessel and Flugge 1984).

\section{Isoelectric focusing and 2D-PAGE.}

2D-PAGE was performed using an immobiline/polyacrylamide system described in detail by Valerius and coworkers (2007). Gels were stained with fluorescent RuBP (Lamanda et al. 2004). After scanning, RuBP-stained gels were additionally stained with silver nitrate (Blum et al. 1987) to visualize the protein spots for excision for trypsin digestion.

\section{Image analysis.}

Images of fluorescent-stained gels were acquired by scanning with the Typhoon 8600 laser scanner (GE Healthcare, Munich). Image analysis was performed using the PDQuest software (Bio-Rad Laboratories GmbH, Munich). By using the spot detection tool, discrete spots were marked by the software. In addition to the automatic spot detection and spot-matching procedures provided by the PDQuest, all gels and all match sets were carefully manually edited and optimized. The signal intensity of each spot was determined in pixel units (optical density) and normalized to the sum of the intensities of all the spots included in a standard gel; that is, the total spots intensity in all the gels is equal. Each matching analysis included six 2DE gels from control samples (three biological replicates, each with two technical replicates) and, similarly, six 2DE gels from samples treated with xylem sap.

\section{Liquid chromatography MS/MS and protein identification.}

Proteins within the excised polyacrylamide gel pieces of the regulated spots were in-gel digested with trypsin (Shevchenko et al. 1996). Sample preparation and liquid chromatography MS/MS analysis were performed as described (Valerius et al. 2007). The "peak list" was created with extract ms provided by the Xcalibur software package (BioworksBrowser 3.1; Thermo Electron Corp., San Jose, CA, U.S.A.). Identification was achieved through homology searching by the TurboSEQUEST analysis software (Eng et al. 1994) which correlated experimental spectra to theoretical spectra. The MS2 spectra with a total ion current higher than 10,000 were used to search for matches against a filamentous fungi database that consists of 10,082 entries of $N$. crassa (Galagan et al. 2003), 9,541 entries of A. nidulans (Galagan et al. 2005), 9,926 entries of A. fumigatus (Nierman et al. 2005), and 14,063 entries of $A$. oryzae (Machida et al. 2005), plus 180 entries of the most commonly appearing contaminants, including keratins or proteases, provided with the BioworksBrowser package using the TurboSEQUEST algorithm (Eng et al. 1994). In addition, the $V$. dahliae COGEME EST database containing 1,455 unisequences (Neumann and Dobinson 2003) was used. The MS2 spectrum of spot U1 was specifically used to search for matches against database of a $V$. longisporum cDNA library sequences containing approximately 2,000 unisequences (Singh et al. 2010). The search parameters included, based on the TurboSEQUEST algorithm, were i) precursor ion mass tolerance less than 1.4 amu, ii) fragment ion mass tolerance less than $1.0 \mathrm{amu}$, iii) up to three missed tryptic cleavages allowed, and iv) fixed cysteine modification by carboxyamidomethylation (plus 57.05 amu) and variable modification by methionine oxidation (plus $15.99 \mathrm{amu}$ ) and phosphorylation of serine, threonine, or tyrosine (plus $79.97 \mathrm{amu}$ ). In accordance with the criteria described by Link and associates (1999), matched peptide sequences of identified proteins had to pass the following: i) the cross-correlation scores (Xcorr) of matches must be greater than 2.0, 2.5, and 3.0 for peptide ions of charge state 1,2 , and 3 , respectively; ii) Cn (delta cross-correlation score) values of the best peptide matches must be at least 0.4 ; and iii) the primary scores (Sp) must be at least 600. Protein identification required at least two different peptides matching these criteria. The degree of completeness of the $b$ - and y-ion series for each TurboSEQUEST result was manually checked for every protein identified. The MS/MS spectra of all the protein spots was also used to verify the TurboSEQUEST results against the NCBI nonredundant database using PEAKS MS program (Bioinformatics Solutions Inc.) (Ma et al. 2003).

\section{DNA isolation and Southern hybridization.}

Primers are listed in Supplementary Table S1. Genomic DNA of $V$. longisporum was isolated from powdered mycelium as described (Kolar et al. 1988). Southern analyses were performed essentially as described earlier (Southern 1975). Gelpurified DNA fragments (QIAquick gel extraction kit; Qiagen, Hilden, Germany) consisting of a 400-bp fragment from catalase peroxidase was used as a probe and labeled using Amersham AlkPhos direct-labeling reagents (GE Healthcare).

\section{Cloning and sequencing \\ of the catalase peroxidase isogenes.}

The two catalase peroxidase-encoding isogenes cpeAl and cpeA2 were cloned from ApaI-digested genomic DNA. The DNA fragments which were identified by Southern hybridization were excised, purified (Qiagen QIAquick gel extraction kit), sequenced, and cloned into pJET1.2. Recombinant plasmids were isolated after colony PCR from transformants of DH5 $\alpha$ by using the QIAprep spin miniprep kit (Qiagen). The sequences of the two isogenes were deposited with the EMBL European Nucleotide Archive. The cpeAl gene has accession number FR717672 and the isogene cpeA2 has number FR717673.

\section{In-gel catalase activity assay.}

The native protein extracts were analyzed by nondenaturing Tris-glycine PAGE, using a modified protocol from Sambrook and associates (1989). The native protein $(10 \mu \mathrm{g})$ was loaded in each well. Electrophoresis was carried out through a stacking gel $(3 \%, \mathrm{pH} 6.8)$ and a separating gel $(7.5 \%, \mathrm{pH} 8.0)$ in Tris $(25 \mathrm{mM})$ and glycine $(192 \mathrm{mM})$ buffer at $\mathrm{pH}$ 8.0. The electrophoresis was performed for about $5 \mathrm{~h}$ at $4^{\circ} \mathrm{C}$ and $100 \mathrm{~V}$ in a Mini-Protean III cell (Bio-Rad Laboratories $\mathrm{GmbH}$ ). 
To perform the catalase activity assay, the native gel was washed three times for 15 min with distilled $\mathrm{H}_{2} \mathrm{O}$, suspended in a solution of $0.01 \mathrm{ml}$ of $30 \% \mathrm{H}_{2} \mathrm{O}_{2}$ in $100 \mathrm{ml}$ of $\mathrm{H}_{2} \mathrm{O}$, and gently rocked for $10 \mathrm{~min}$. The $\mathrm{H}_{2} \mathrm{O}_{2}$ solution was then removed and the gel quickly rinsed in $\mathrm{H}_{2} \mathrm{O}$. A freshly prepared mixture of $30 \mathrm{ml}$ each of $2 \%$ ferric chloride and $2 \%$ potassium ferricyanide, both in $\mathrm{H}_{2} \mathrm{O}$, was poured into a fresh staining pan, and the rinsed gel transferred to the ferricyanide mixture (Zou and Schrempf 2000). The gel tray was gently but steadily rocked by hand over a light box. As soon as a green color began to appear in the gel itself, the ferricyanide mixture was rapidly removed and replaced with water. The gel was washed twice with water. The gel was scanned using a GS 700 Imaging Densitometer (Bio-Rad Laboratories $\mathrm{GmbH}$ ). To quantify the catalase activity in the different lanes, the Kodak Molecular Imaging 4.05 software (Eastman Kodak Company) was used.

\section{Silencing VlcpeA in $V$. longisporum.}

The vector pFANTAi4 (Krajaejun et al. 2007) used for the silencing strategy in $V$. longisporum was based on pSilent-1 vector (Nakayashiki 2005). The 495-bp VlcpeA fragment from the coding region was amplified using primers CatPerV-F and CatPerV-R and restricted by SnaB1 and HindIII for the sense strand. Primers CatPerH-F and CatPerH-R were used for the antisense strand and digested by $A p a \mathrm{I}$ and $S p h 1$. Both fragments were inserted into pFANTAi4, resulting in a VlcpeA hairpin construct consisting of inverted repeats separated by a spacer. The entire silencing cassette was isolated as an $\mathrm{XbaI}$ fragment and inserted into the binary vector pPK2 (Covert et al. 2001) which contains the hygromycin B phosphotransferase gene as selection marker. The generated plasmid was pME3928 and was transformed into V. longisporum strain 43 by Agrobacterium tumefaciens-mediated transformation (Mullins et al. 2001). A. tumefaciens AGL-1 strain (Lazo et al. 1991) was transformed with plasmids using Luria-Bertani medium containing kanamycin $\left(100 \mu \mathrm{g} \mathrm{ml}^{-1}\right)$. Filter paper $(90 \mathrm{~mm})$ (Sartorius) was used for co-cultivation of the A. tumefaciens culture and the $V$. longisporum spore suspension. The transformants were grown on medium lacking hygromycin B for five generations and then plated on selective medium supplemented with hygromycin B at $100 \mu \mathrm{g} \mathrm{ml}^{-1}$, where only mitotically stable transformants could grow (Singh et al. 2010).

\section{Stress tests.}

$V$. longisporum wild-type and mutants strains were grown on CDA and on CDA containing different substances inducing oxidative and redox-membrane stress. Experiments were repeated three times. Plates were supplemented with $\mathrm{H}_{2} \mathrm{O}_{2}(2$ and $5 \mathrm{mM}$ ), EtOH ( 3 and $4 \%$ ), SDS (2.5 and $5 \mathrm{mM}$ ), or menadione ( 25 and $50 \mathrm{mM}$ ) for 4 days at $25^{\circ} \mathrm{C}$.

\section{Pathogenicity assay.}

One-week-old $B$. napus seedlings were inoculated with VlcpeAsm and the wild type $(\mathrm{Vl} 43)$ at $1 \times 10^{6}$ spores $/ \mathrm{ml}$ and mock inoculated with sterile tap water for $30 \mathrm{~min}$ by root-dipping inoculation. They were then transferred in pots with a sterile sand/soil (1:1) mixture. The plants were incubated in a climate chamber with $14 \mathrm{~h}$ of light at $23^{\circ} \mathrm{C}$ and $10 \mathrm{~h}$ of darkness at $20^{\circ} \mathrm{C}$. The height of inoculated plants was measured and disease symptoms were scored (Eynck et al. 2007). Statistical data analyses were performed with a program (Statgraph Centurion XV, St. Louis).

\section{Quantification of gene expression and $V$. longisporum DNA in planta by real-time PCR.}

Hypocotyls, stems (5 to $6 \mathrm{~cm}$ from top of plant), and roots were separated from the infected rapeseed plants harvested at
$14,21,28$, and 35 dpi. In total, 20 plants were harvested from each treatment and fungal DNA and RNA was quantified using primers OLG 70 and OLG 71 for amplification of a specific Verticillium fragment encoding parts of the 5S rRNA (Eynck et al. 2007). VlcpeA was amplified using primers Cat2left and Cat2right and the histone gene using primers H2aleft and H2aright. Real-time PCR was carried out as described by Singh and associates (2010). The amount of DNA of V. longisporum was estimated by integration of a calibration curve using increasing amounts of genomic $V$. longisporum DNA from 1 to $625 \mathrm{pg}$ in the analysis. The real-time RT-PCR data were analyzed using the $2-\Delta \Delta \mathrm{Ct}$ relative quantification method (Livak and Schmittgen 2001), taking the gene for histone as reference for normalization.

\section{ACKNOWLEDGMENTS}

We thank P. Findeisen for fruitful technical assistance during the initial phase of the project, V.-T. Tran and H. Kusch for helpful discussions, M. Franke-Klein for excellent technical assistance with xylem sap assays; and all members of the DFG research group for the excellent collaboration. This work was funded by the DFG research group FOR546 and the BMBF BioFung project.

\section{LITERATURE CITED}

Andersen, P. C., Brodbeck, B. V., Oden, S., Shriner, A., and Leite, B. 2007. Influence of xylem fluid chemistry on planktonic growth, biofilm formation and aggregation of Xylella fastidiosa. FEMS (Fed. Eur. Microbiol. Soc.) Microbiol. Lett. 274:210-217.

Apostol, I., Heinstein, P. F., and Low, P. S. 1989. Rapid stimulation of an oxidative burst during elicitation of cultured plant cells: Role in defense and signal transduction. Plant Physiol. 90:109-116.

Avrova, A. O., Venter, E., Birch, P. R., and Whisson, S.C. 2003. Profiling and quantifying differential gene transcription in Phytophthora infestans prior to and during the early stages of potato infection. Fungal Genet. Biol. 40:4-14.

Babiychuk, E., Kushnir, S., Belles-Boix, E., Van Montagu, M., and Inze, D. 1995. Arabidopsis thaliana NADPH oxidoreductase homologs confer tolerance of yeasts toward the thiol-oxidizing drug diamide. J. Biol. Chem. 270:26224-26231.

Babujee, L., Venkatesh, B., Yamazaki, A., and Tsuyumu, S. 2007. Proteomic analysis of the carbonate insoluble outer membrane fraction of the soft-rot pathogen Dickeya dadantii (syn. Erwinia chrysanthemi) strain 3937. J. Proteome Res. 6:62-69.

Barbara, D. J., Morton, A., and Miller, N. J. 2005. Isolation of microsatellite markers from an interspecific hybrid isolate of the fungal plant pathogen Verticillium dahliae. Mol Ecol. Notes 5:854-856.

Bhadauria, V., Zhao, W. S., Wang, L. X., Zhang, Y., Liu, J. H., Yang, J., Kong, L. A., and Peng, Y. L. 2007. Advances in fungal proteomics. Microbiol. Res. 162:193-200.

Blum, H., Eyer, H., and Gross, H. J. 1987. Improved silver staining of plant proteins, RNA and DNA in polyacrylamide gels. Electrophoresis 8:93-99.

Busch, S., Eckert, S. E., Krappmann, S., and Braus, G. H. 2003. The COP9 signalosome is an essential regulator of development in the filamentous fungus Aspergillus nidulans. Mol. Microbiol. 49:717-730.

Bussink, H. J., and Osmani, S. A. 1998. A cyclin-dependent kinase family member (PHOA) is required to link developmental fate to environmental conditions in Aspergillus nidulans. EMBO (Eur. Mol. Biol. Organ.) J. 17:3990-4003.

Cabiscol, E., Belli, G., Tamarit, J., Echave, P., Herrero, E., and Ros, J. 2002. Mitochondrial Hsp60, resistance to oxidative stress, and the labile iron pool are closely connected in Saccharomyces cerevisiae. J. Biol. Chem. 277:44531-44538.

Chary, P., and Natvig, D. O. 1989. Evidence for three differentially regulated catalase genes in Neurospora crassa: Effects of oxidative stress, heat shock, and development. J. Bacteriol. 171:2646-2652.

Chi, M. H., Park, S. Y., Kim, S., and Lee, Y. H. 2009. A novel pathogenicity gene is required in the rice blast fungus to suppress the basal defenses of the host. PLoS Pathog. 5:e1000401. Published online.

Covert, S. F., Kapoor, P., Lee, M., Briley, A., and Nairn, C. J. 2001. Agrobacterium tumefaciens-mediated transformation of Fusarium circinatum. Mycol. Res. 105:259-264.

Daebeler, F., Amelung, D., and Zeise, K. 1988. Verticillium-Welke an Winterraps Auftreten und Bedeutung. Nachrichtenbl. Pflanzenschutzdienst DDR 42:71-73. 
Dschida, W. J., and Bowman, B. J. 1995. The vacuolar ATPase: Sulfite stabilization and the mechanism of nitrate inactivation. J. Biol. Chem. 270:1557-1563.

Dunker, S., Keunecke, H., and von Tiedemann, A. 2006. Verticillium longisporum in winter oilseed rape-impact on plant development and yield. Integr. Control Oilseed Crops 29:365-374.

Egan, M. J., Wang, Z. Y., Jones, M. A., Smirnoff, N., and Talbot, N. J. 2007. Generation of reactive oxygen species by fungal NADPH oxidases is required for rice blast disease. Proc. Natl. Acad. Sci. U.S.A. 104:11772-11777.

El-Bebany, A. F., Rampitsch, C., and Daayf, F. 2010. Proteomic analysis of the phytopathogenic soilborne fungus Verticillium dahliae reveals differential protein expression in isolates that differ in aggressiveness. Proteomics 10:289-303

Eng, J. K., McCormack, A. L., and Yates, J. R., III 1994. An approach to correlate tandem mass spectral data of peptides with amino acid sequences in a protein database. J. Am. Soc. Mass Spectrom. 5:976-989.

Eynck, C., Koopmann, B., Grunewaldt-Stoecker, G., Karlovsky, P., and von Tiedemann, A. 2007. Differential interactions of Verticillium longisporum and $V$. dahliae with Brassica napus detected with molecular and histological techniques. Eur. J. Plant Pathol. 118:259-274.

Floerl, S., Druebert, C., Majcherczyk, A., Karlovsky, P., Kues, U., and Polle, A. 2008. Defence reactions in the apoplastic proteome of oilseed rape (Brassica napus var. napus) attenuate Verticillium longisporum growth but not disease symptoms. BMC Plant Biol. 8:129.

Forgac, M. 1989. Structure and function of vacuolar class of ATP-driven proton pumps. Physiol. Rev. 69:765-796.

Galagan, J. E., Calvo, S. E., Borkovich, K. A., Selker, E. U., Read, N. D., Jaffe, D., FitzHugh, W., Ma, L. J., Smirnov, S., Purcell, S., Rehman, B., Elkins, T., Engels, R., Wang, S., Nielsen, C. B., Butler, J., Endrizzi, M., Qui, D., Ianakiev, P., Bell-Pedersen, D., Nelson, M. A., WernerWashburne, M., Selitrennikoff, C. P., Kinsey, J. A., Braun, E. L., Zelter, A., Schulte, U., Kothe, G. O., Jedd, G., Mewes, W., Staben, C., Marcotte, E., Greenberg, D., Roy, A., Foley, K., Naylor, J., Stange-Thomann, N., Barrett, R., Gnerre, S., Kamal, M., Kamvysselis, M., Mauceli, E., Bielke, C., Rudd, S., Frishman, D., Krystofova, S., Rasmussen, C., Metzenberg, R. L., Perkins, D. D., Kroken, S., Cogoni, C., Macino, G., Catcheside, D., Li, W., Pratt, R. J., Osmani, S. A., DeSouza, C. P., Glass, L., Orbach, M. J., Berglund, J. A., Voelker, R., Yarden, O., Plamann, M., Seiler, S., Dunlap, J., Radford, A., Aramayo, R., Natvig, D. O., Alex, L. A., Mannhaupt, G., Ebbole, D. J., Freitag, M., Paulsen, I., Sachs, M. S., Lander, E. S., Nusbaum, C., and Birren, B. 2003. The genome sequence of the filamentous fungus Neurospora crassa. Nature 422:859-868.

Galagan, J. E., Calvo, S. E., Cuomo, C., Ma, L. J., Wortman, J..R., Batzoglou, S., Lee, S. I., Basturkmen, M., Spevak, C. C., Clutterbuck, J., Kapitonov, V., Jurka, J., Scazzocchio, C., Farman, M., Butler, J., Purcell, S., Harris, S., Braus, G. H., Draht, O., Busch, S., D’Enfert, C., Bouchier, C., Goldman, G. H., Bell-Pedersen, D., Griffiths-Jones, S., Doonan, J. H., Yu, J., Vienken, K., Pain, A., Freitag, M., Selker, E. U., Archer, D. B., Penalva, M. A., Oakley, B. R., Momany, M., Tanaka, T. Kumagai, T., Asai, K., Machida, M., Nierman, W. C., Denning, D. W., Caddick, M., Hynes, M., Paoletti, M., Fischer, R., Miller, B., Dyer, P., Sachs, M. S., Osmani, S. A., and Birren, B. W. 2005. Sequencing of Aspergillus nidulans and comparative analysis with $A$. fumigatus and $A$. oryzae. Nature 438:1105-1115.

Garre, V., Tenberge, K. B., and Eising, R. 1998. Secretion of a fungal extracellular catalase by Claviceps purpurea during infection of rye: Putative role in pathogenicity and suppression of host defense. Phytopathology 88:744-753.

Grenville-Briggs, L. J., Avrova, A. O., Bruce, C. R., Williams, A., Whisson, S. C., Birch, P. R., and van West, P. 2005. Elevated amino acid biosynthesis in Phytophthora infestans during appressorium formation and potato infection. Fungal Genet. Biol. 42:244-256.

Günzelmann, H., and Paul, V. H. 1990. Zum Auftreten und zur Bedeutung der Verticillium-Welke an Raps in der Bundesrepublik Deutschland in 1989. Raps 8:23-25.

Hammond-Kosack, K. E., and Jones, J. D. 1996. Resistance gene-dependent plant defense responses. Plant Cell 8:1773-1791.

Hershey, J. W. 1991. Translational control in mammalian cells. Annu. Rev. Biochem. 60:717-755.

Huang, K., Czymmek, K. J., Caplan, J. L., Sweigard, J. A., and Donofrio, N. M. 2011. HYR1-mediated detoxification of reactive oxygen species is required for full virulence in the rice blast fungus. PLoS Pathog. 7:e1001335. Published online.

Huisman, O. C. 1982. Interrelations of root growth dynamics to epidemiology of root-invading fungi. Annu. Rev. Phytopathol. 20:303-327.

Inderbitzin, P., Davis, R. M., Bostock, R. M., and Subbarao, K. V. 2011. The ascomycete Verticillium longisporum is a hybrid and a plant pathogen with an expanded host range. PLoS One 6:e18260. Published online.
Jordan, M. C., Cloutier, S., Somers, D., and Procunier, D. 2006. Beyond R genes: Dissecting disease-resistance pathways using genomics and proteomics. Can. J. Plant Pathol. 28:228-232.

Judah, D. J., Hayes, J. D., Yang, J. C., Lian, L. Y., Roberts, G. C., Farmer, P. B., Lamb, J. H., and Neal, G. E. 1993. A novel aldehyde reductase with activity towards a metabolite of aflatoxin B1 is expressed in rat liver during carcinogenesis and following the administration of an antioxidant. Biochem. J. 292:13-18.

Karapapa, V. K., Bainbridge, B. W., and Heale, J. B. 1997. Morphological and molecular characterization of Verticillium longisporum comb. nov., pathogenic to oilseed rape. Mycol. Res. 101:1281-1293.

Kawasaki, L., and Aguirre, J. 2001. Multiple catalase genes are differentially regulated in Aspergillus nidulans. J. Bacteriol. 183:1434-1440.

Kehr, J., Buhtz, A., and Giavalisco, P. 2005. Analysis of xylem sap proteins from Brassica napus. BMC Plant Biol. 5:11.

Kim, K. H., Willger, S. D., Park, S. W., Puttikamonkul, S., Grahl, N., Cho, Y., Mukhopadhyay, B., Cramer, R. A., Jr., and Lawrence, C. B. 2009 TmpL, a transmembrane protein required for intracellular redox homeostasis and virulence in a plant and an animal fungal pathogen. PLoS Pathog. 5:e1000653. Published online.

Klimes, A., and Dobinson, K. F. 2006. A hydrophobin gene, VDH1, is involved in microsclerotial development and spore viability in the plant pathogen Verticillium dahliae. Fungal Genet. Biol. 43:283-294.

Klosterman, S. J., Subbarao, K. V., Kang, S., Veronese, P., Gold, S. E., Thomma, B. P., Chen, Z., Henrissat, B., Lee, Y. H., Park, J., GarciaPedrajas, M. D., Barbara, D. J., Anchieta, A., de Jonge, R., Santhanam, P., Maruthachalam, K., Atallah, Z., Amyotte, S. G., Paz, Z., Inderbitzin, P., Hayes, R. J., Heiman, D. I., Young, S., Zeng, Q., Engels, R., Galagan, J., Cuomo, C. A., Dobinson, K. F., and Ma, L. J. 2011. Comparative genomics yields insights into niche adaptation of plant vascular wilt pathogens. PLoS Pathog. 7:e1002137. Published online.

Knecht, K., Seyffarth, M., Desel, C., Thurau, T., Sherameti, I., Lou, B. G., Oelmuller, R., and Cai, D. G. 2010. Expression of BvGLP-1 encoding a germin-like protein from sugar beet in Arabidopsis thaliana leads to resistance against phytopathogenic fungi. Mol. Plant-Microbe Interact. 23:446-457.

Kolar, M., Punt, P. J., van den Hondel, C. A., and Schwab, H. 1988. Transformation of Penicillium chrysogenum using dominant selection markers and expression of an Escherichia coli lacZ fusion gene. Gene 62:127-134.

Krajaejun, T., Gauthier, G. M., Rappleye, C. A., Sullivan, T. D., and Klein, B. S. 2007. Development and application of a green fluorescent protein sentinel system for identification of RNA interference in Blastomyces dermatitidis illuminates the role of septin in morphogenesis and sporulation. Eukaryot. Cell 6:1299-1309.

Kroeker, G. 1976. Verticillium dahliae on Brassica oil seed crops in Sweden. Pages 28-29 in: 2nd Int. Verticillium Symp. Berkeley, CA U.S.A.

Lamanda, A., Zahn, A., Roder, D., and Langen, H. 2004. Improved Ruthenium II Tris (bathophenantroline disulfonate) staining and destaining protocol for a better signal-to-background ratio and improved baseline resolution. Proteomics 4:599-608.

Lamb, C., and Dixon, R. A. 1997. The oxidative burst in plant disease resistance. Annu. Rev. Plant Physiol. Plant Mol. Biol. 48:251-275.

Lash, T. D., Mani, U. N., Drinan, M. A., Zhen, C., Hall, T., and Jones, M. A. 1999. Normal and abnormal heme biosynthesis. 1. Synthesis and metabolism of $\mathrm{Di}$ - and monocarboxylic porphyrinogens related to coproporphyrinogen-III and harderoporphyrinogen: A model for the active site of coproporphyrinogen Oxidase. J. Org. Chem. 64:464-477.

Lazo, G. R., Stein, P. A., and Ludwig, R. A. 1991. A DNA transformationcompetent Arabidopsis genomic library in Agrobacterium. Biotechnology 9:963-967

Link, A. J., Eng, J., Schieltz, D. M., Carmack, E., Mize, G. J., Morris, D. R., Garvik, B. M., and Yates, J. R., 3rd. 1999. Direct analysis of protein complexes using mass spectrometry. Nat. Biotechnol. 17:676-682.

Livak, K. J., and Schmittgen, T. D. 2001. Analysis of relative gene expression data using real-time quantitative PCR and the $2^{-\Delta \Delta \mathrm{Ct}}$ method. Methods 25:402-408.

Lopez-Millan, A. F., Morales, F., Abadia, A., and Abadia, J. 2000. Effects of iron deficiency on the composition of the leaf apoplastic fluid and xylem sap in sugar beet. Implications for iron and carbon transport. Plant Physiol. 124:873-884.

Lu, Z. X., Gaudet, D., Puchalski, B., and Despins, T. 2006. Inducers of resistance reduce common bunt infection in wheat seedlings while differentially regulating defense-gene expression. Physiol. Mol. Plant Pathol. 67:138-148.

Ma, B., Zhang, K., Hendrie, C., Liang, C., Li, M., Doherty-Kirby, A., and Lajoie, G. 2003. PEAKS: Powerful software for peptide de novo sequencing by tandem mass spectrometry. Rapid Commun. Mass Spectrom. 17:2337-2342.

Machida, M., Asai, K., Sano, M., Tanaka, T., Kumagai, T., Terai, G., 
Kusumoto, K., Arima, T., Akita, O., Kashiwagi, Y., Abe, K., Gomi, K., Horiuchi, H., Kitamoto, K., Kobayashi, T., Takeuchi, M., Denning, D. W., Galagan, J. E., Nierman, W. C., Yu, J., Archer, D. B., Bennett, J. W., Bhatnagar, D., Cleveland, T. E., Fedorova, N. D., Gotoh, O., Horikawa, H., Hosoyama, A., Ichinomiya, M., Igarashi, R., Iwashita, K., Juvvadi, P. R., Kato, M., Kato, Y., Kin, T., Kokubun, A., Maeda, H., Maeyama, N., Maruyama, J., Nagasaki, H., Nakajima, T., Oda, K., Okada, K., Paulsen, I., Sakamoto, K., Sawano, T., Takahashi, M., Takase, K., Terabayashi, Y., Wortman, J. R., Yamada, O., Yamagata, Y., Anazawa, H., Hata, Y., Koide, Y., Komori, T., Koyama, Y., Minetoki, T., Suharnan, S., Tanaka, A., Isono, K., Kuhara, S., Ogasawara, N., and Kikuchi, H. 2005. Genome sequencing and analysis of Aspergillus oryzae. Nature 438:1157-1161.

Mattinen, L., Nissinen, R., Riipi, T., Kalkkinen, N., and Pirhonen, M. 2007. Host-extract induced changes in the secretome of the plant pathogenic bacterium Pectobacterium atrosepticum. Proteomics 7:35273537.

Mayer, A. M., Staples, R. C., and Gil-ad, N. L. 2001. Mechanisms of survival of necrotrophic fungal plant pathogens in hosts expressing the hypersensitive response. Phytochemistry 58:33-41.

Medentsev, A. G., Arinbasarova, A. I., and Aimenko, V. K. 2001. Adaptation of the phytopathogenic fungus Fusarium decemcellulare to oxidative stress. Mikrobiologiia 70:34-38.

Mol, L., Scholte, K., and Vos, J. 1995. Effects of crop rotation and removal of crop debris on the soil population of two isolates of Verticillium dahliae. Plant Pathol. 44:1070-1074.

Mullins, E. D., Chen, X., Romaine, P., Raina, R., Geiser, D. M., and Kang, S. 2001. Agrobacterium-mediated transformation of Fusarium oxysporum: An efficient tool for insertional mutagenesis and gene transfer. Phytopathology 91:173-180.

Nahlik, K., Dumkow, M., Bayram, O., Helmstaedt, K., Busch, S., Valerius, O., Gerke, J., Hoppert, M., Schwier, E., Opitz, L., Westermann, M., Grond, S., Feussner, K., Goebel, C., Kaever, A., Meinicke, P., Feussner, I., and Braus, G. H. 2010. The COP9 signalosome mediates transcriptional and metabolic response to hormones, oxidative stress protection and cell wall rearrangement during fungal development. Mol. Microbiol. 78:964-979.

Nakayashiki, H. 2005. RNA silencing in fungi: Mechanisms and applications. FEBS (Fed. Eur. Biochem. Soc.) Lett. 579:5950-5957.

Nathues, E., Joshi, S., Tenberge, K. B., von den Driesch, M., Oeser, B., Baumer, N., Mihlan, M., and Tudzynski, P. 2004. CPTF1, a CREB-like transcription factor, is involved in the oxidative stress response in the phytopathogen Claviceps purpurea and modulates ROS level in its host Secale cereale. Mol. Plant-Microbe Interact. 17:383-393.

Nell, M., Mammerler, R., and Steinkellner, S. 2006. Oxygen consumptionbased evaluation of fungal activity. Mycol. Res. 110 (Pt 7):760-764

Neumann, M. J., and Dobinson, K. F. 2003. Sequence tag analysis of gene expression during pathogenic growth and microsclerotia development in the vascular wilt pathogen Verticillium dahliae. Fungal Genet. Biol. 38:54-62.

Nierman, W. C., Pain, A., Anderson, M. J., Wortman, J. R., Kim, H. S., Arroyo, J., Berriman, M., Abe, K., Archer, D. B., Bermejo, C., Bennett, J., Bowyer, P., Chen, D., Collins, M., Coulsen, R., Davies, R., Dyer, P. S., Farman, M., Fedorova, N., Fedorova, N., Feldblyum, T. V., Fischer, R., Fosker, N., Fraser, A., Garcia, J. L., Garcia, M. J., Goble, A., Goldman, G. H., Gomi, K., Griffith-Jones, S., Gwilliam, R., Haas, B., Haas, H., Harris, D., Horiuchi, H., Huang, J., Humphray, S., Jimenez, J., Keller, N., Khouri, H., Kitamoto, K., Kobayashi, T., Konzack, S., Kulkarni, R., Kumagai, T. Lafon, A., Latge, J. P., Li, W., Lord, A., Lu, C., Majoros, W. H., May, G. S., Miller, B. L., Mohamoud, Y., Molina, M., Monod, M., Mouyna, I., Mulligan, S., Murphy, L., O'Neil, S., Paulsen, I., Penalva, M. A., Pertea, M., Price, C., Pritchard, B. L., Quail, M. A., Rabbinowitsch, E., Rawlins, N., Rajandream, M. A., Reichard, U., Renauld, H., Robson, G. D., Rodriguez de Cordoba, S., Rodriguez-Pena, J. M., Ronning, C. M., Rutter, S., Salzberg, S. L., Sanchez, M., Sanchez-Ferrero, J. C., Saunders, D., Seeger, K., Squares, R., Squares, S., Takeuchi, M., Tekaia, F., Turner, G., Vazquez de Aldana, C. R., Weidman, J., White, O., Woodward, J., Yu, J. H., Fraser, C., Galagan, J. E., Asai, K., Machida, M., Hall, N., Barrell, B., and Denning, D. W. 2005. Genomic sequence of the pathogenic and allergenic filamentous fungus Aspergillus fumigatus. Nature 438:11511156.

Ratzinger, A., Riediger, N., von Tiedemann, A., and Karlovsky, P. 2009. Salicylic acid and salicylic acid glucoside in xylem sap of Brassica napus infected with Verticillium longisporum. J. Plant Res. 122:571-579.

Roman, D. G., Dancis, A., Anderson, G. J., and Klausner, R. D. 1993. The fission yeast ferric reductase gene frp1+ is required for ferric iron uptake and encodes a protein that is homologous to the gp91-phox subunit of the human NADPH phagocyte oxidoreductase. Mol. Cell Biol. 13:4342-4350.
Sambrook, J., Fritsch, E. F., and Maniatis, T. 1989. Molecular Cloning: A Laboratory Manual. Cold Spring Harbor Laboratory Press, Cold Spring Harbor, NY, U.S.A

Scherer, M., Wei, H., Liese, R., and Fischer, R. 2002. Aspergillus nidulans catalase peroxidase gene (cpeA) is transcriptionally induced during sexual development through the transcription factor StuA. Eukaryot. Cell $1: 725-735$.

Schurr, U., and Schulze, E.-D. 1995. The concentration of xylem sap constituents in root exudate, and in sap from intact, transpiring castor bean plants (Ricinus communis L.). Plant Cell Environ. 18:409-420.

Scott, B., and Eaton, C. J. 2008. Role of reactive oxygen species in fungal cellular differentiations. Curr. Opin. Microbiol. 11:488-493.

Shevchenko, A., Wilm, M., Vorm, O., and Mann, M. 1996. Mass spectrometric sequencing of proteins silver-stained polyacrylamide gels. Anal Chem. 68:850-858.

Singh, S., Braus-Stromeyer, S. A., Timpner, C., Tran, V. T., Lohaus, G., Reusche, M., Knufer, J., Teichmann, T., von Tiedemann, A., and Braus, G. H. 2010. Silencing of Vlaro2 for chorismate synthase revealed that the phytopathogen Verticillium longisporum induces the cross-pathway control in the xylem. Appl. Microbiol. Biotechnol. 85:1961-1976.

Skamnioti, P., Henderson, C., Zhang, Z., Robinson, Z., and Gurr, S. J. 2007. A novel role for catalase $B$ in the maintenance of fungal cell-wall integrity during host invasion in the rice blast fungus Magnaporthe grisea. Mol. Plant-Microbe Interact. 20:568-580.

Southern, E. M. 1975. Detection of specific sequences among DNA fragments separated by gel electrophoresis. J. Mol. Biol. 98:503-517.

Taborda, C. P., da Silva, M. B., Nosanchuk, J. D., and Travassos, L. R. 2008. Melanin as a virulence factor of Paracoccidioides brasiliensis and other dimorphic pathogenic fungi: A minireview. Mycopathologia $165: 331-339$

Tilsner, J., Kassner, N., Struck, C., and Lohaus, G. 2005. Amino acid contents and transport in oilseed rape (Brassica napus L.) under different nitrogen conditions. Planta 221:328-338.

Valerius, O., Kleinschmidt, M., Rachfall, N., Schulze, F., Lopez Marin, S., Hoppert, M., Streckfuss-Bomeke, K., Fischer, C., and Braus, G. H. 2007. The Saccharomyces homolog of mammalian RACK1, Cpc2/ Asc1p, is required for FLO11-dependent adhesive growth and dimorphism. Mol. Cell. Proteomics 6:1968-1979.

van Loon, L. C., Rep, M., and Pieterse, C. M. J. 2006. Significance of inducible defense-related proteins in infected plants. Annu. Rev. Phytopathol. 44:135-162.

Wessel, D., and Flugge, U. I. 1984. A method for the quantitative recovery of protein in dilute solution in the presence of detergents and lipids. Anal. Biochem. 138:141-143.

Williams, P. H., and Hill, C. B. 1986. Rapid-cycling populations of Brassica. Science 232:1385-1389.

Wojtaszek, P. 1997. Oxidative burst: An early plant response to pathogen infection. Biochem. J. 322:681-692.

Wysong, D. R., Christin, L., Sugar, A. M., Robbins, P. W., and Diamond, R. D. 1998. Cloning and sequencing of a Candida albicans catalase gene and effects of disruption of this gene. Infect. Immun. 66:1953-1961.

Xu, X. Q., and Pan, S. Q. 2000. An Agrobacterium catalase is a virulence factor involved in tumorigenesis. Mol. Microbiol. 35:407-414.

Zamocky, M., Regelsberger, G., Jakopitsch, C., and Obinger, C. 2001. The molecular peculiarities of catalase-peroxidases. FEBS (Fed. Eur. Biochem. Soc.) Lett. 492:177-182.

Zeise, K., and Seidel, D. 1990. Zur Entwicklung und Schadwirkung der Verticillium Welkekrankheit am Winterraps. Raps 8:20-22.

Zeise, K., and von Tiedemann, A. 2002a. Host specialization among vegetative compatibility groups of Verticillium dahliae in relation to Verticillium longisporum. J. Phytopathol. 150:112-119.

Zeise, K., and von Tiedemann, A. 2002b. Application of RAPD-PCR for virulence type analysis within Verticillium dahliae and V. longisporum J. Phytopathol. 150:557-563.

Zielinski, D., and Sadowski, C. 1995. A preliminary study on Verticillium dahliae Kleb. in winter oilseed rape in Poland. Pages 649-651 in: 9th Int. GCIRC Rapeseed Congr. F28: Pests and Diseases. Cambridge.

Zornoza, P., Gonzalez, M., Serrano, S., and Carpena, O. 1996. Intervarietal differences in xylem exudate composition and growth under contrasting forms of N supply in cucumber. Plant Soil 178:311-317.

Zou, P., and Schrempf, H. 2000. The heme-independent manganese-peroxidase activity depends on the presence of the $\mathrm{C}$-terminal domain within the Streptomyces reticuli catalase-peroxidase CpeB. Eur. J. Biochem. 267:2840-2849.

\section{AUTHOR-RECOMMENDED INTERNET RESOURCE}

European Molecular Biology Laboratory (EMBL) website: www.embl.de 